상징과모래놀이치료, 제 11 권 제 1 호

Journal of Symbols \& Sandplay Therapy

2020, 6, Vol. 11, No. 1, 99-123.

doi https://doi.org/10.12964/jsst.20003

\title{
A Research on the Turtle's Symbolic Ambivalence and Its Role as a Spiritual Guide for Individuation Entrance
}

\author{
Hwang, Hwa Ran
}

\begin{abstract}
$<$ Abstract $>$
Individuation is a process of human maturity into true self, and a process of self-realization, a holistic process centered on spiritual transformation. Individuation incorporates the unconsciousness and consciousness existing as an antipole within the mind. We examine this process through the common symbol of the turtle in sandplay therapy. It serves as a mediator between God and Man, thus having an antipole ambivalence of wisdom and chaos. Our case study to examine the role of this symbol was a middle-aged woman. Through turtles appearing in sand therapy of middle-aged woman, we recognized and integrated what is symbolic of human unconsciousness. Sandplay both illuminated and resolved her anger and internal conflict. This fostered the process of individualization and integrated the anima and animus. The results are relevant for understanding the individuation entrance in sandplay therapy. In particular, it aids struggles with self-integration and individualization because of internal conflicts.
\end{abstract}

Keywords : sandplay, symbol, self-integration, individualization, unconsciousness

\footnotetext{
* Ph.D. candidate in Child Counseling and Psychotherapy, Department of Child Welfare, The Graduate School
} of Namseoul University, Dongjag Children's Development Center, Play Therapist (hhr4908@hanmail.net) 
Journal of Symbols \& Sandplay Therapy, Vol.11 No.1.

\section{I . Introduction}

The human unconscious is revealed and expressed through symbols. Symbols of the unconscious can be manifested in the form of emotions. In modern times, many suffer from psychological difficulties associated with anxiety and depression and easily experience physical and psychological fatigue as well as helplessness. Because they can't find meaning in life, they feel lost and frustrated and also struggle with an identity crisis of who am I. Also, a considerable number of people go through a midlife crisis, feeling bored and passionless and therefore distressed. They feel anxious, depressed and also alienated, having a hard time adapting to ever-changing social circumstances and environment (Kim, 2001).

The issue of "finding meaning in life" faced by those going through a midlife crisis can be resolved only when they discover the shadows in the unconscious, i.e., their complexes. This is what Carl Jung meant when he talked about the need to encounter one's roots. The work involves integrating the unconscious, which lies at the core of the essential aspects of our life.

Jung used the term "individualization process" to describe the universal, primitive drive for self-realization in us. Individuation is about becoming a unique individual, unleashing and integrating one's innate psychic aspects to make the Self whole (Rhi, 2002). While we learn more about ourselves through individuation, with it comes conflicts and pain. Thus, the individuation process requires strong determination, courage, and patience on the part of the ego so as to overcome those conflicts and pain (Winckel, 2010). While going through the process of individualization, the hidden or unknown aspects of the unconscious surface to the conscious. If we correctly grasp the meaning of the symbols of our unconscious, the world of our conscious becomes more profound.

Jung said that the symbol of the Self, which manifests in the process of integrating the conscious and the unconscious, can appear in the form of animals. Suggested images are elephants, horses, bulls, bears, black and white birds, fish, snakes, and turtles (Gillotti, 2002). Among them, the turtle has long been worshipped in Korea and China as one of four sacred animals along with the dragon, phoenix, and white tiger. Among them, the turtle is the only 
animal that exists in outer reality today.

Turtles carry a hard shell in the form of a mandala on their back. They are amphibious, meaning that they can live on both land and water. Because they can travel freely between the mundane world and the spiritual world, they were considered as a messenger of the gods (Cheon, 2003).

For many years, turtles have symbolized longevity, steadfastness, knowing, protection, and growth. In Eastern and Western mythologies, turtles are described as spiritual animals associated with longevity and a symbol of wisdom as they are well versed in the mysteries of the heavens and the earth. And because they can travel between land and water, they are represented as a messenger of the gods. According to Ryce-Menuhin (1992), given the turtle's hard shell for protection, its presence in sandplay therapy can be a representation of self-defense on the part of the client.

Analytical psychology, the theoretical basis of sandplay therapy, puts importance on dream analysis as a process of exploring human unconsciousness. Through dreams, we often encounter profound symbols of human unconsciousness. When certain animals appear in dreams or sandpictures, we need to pay a particular attention to their symbolisms. Turtles that appear during sandplay therapy processes could be a symbol of the Self, the union between the conscious and the unconscious, and the beginning of the journey of individuation.

This paper analyzed a dream of a middle-aged woman client that she had during her sandplay process and examined her process of individuation, through which she met her "true self-image" with the help of the turtle symbol. In the dream, a golden turtle with a mandala-shaped shell emerged from golden sand, carried her on its back, and went out to the sea.

\section{Biological characteristics of turtles}

All symbols are related to the shape and the functionalities of their representations. Therefore, we must first look into the biological characteristics of the turtle in order to 
Journal of Symbols \& Sandplay Therapy, Vol.11 No.1.

understand its symbolisms. The biological characteristics of animal species are common, regardless of the era or geographical region. The turtle is the oldest reptile of the order Testudines. Comprised of the head, neck, body, tail, and limbs, the turtle has a rather bizarre body plan compared to other animals. The body is surrounded by a hard shell, and its carapace and plastron form a unique pattern. When it is in a stake of shock or at rest, it retracts its head, legs and tail into the shell for protection (Global World Encyclopedia, 1970).

Contrary to other vertebrates, the turtle's carapace represents transformed vertebrae, ribs and scapula, or shoulder blades. Offering protection, the carapace is the main reason why turtles were able to survive amid various environmental crises. The heavy, hard shell makes it possible for the turtle to have special supporting structures and appropriate muscular systems. Therefore, the turtle can store more water and food in its body than other reptile species. The female turtle can lay a large number of eggs at a time. Turtles lack a diaphragm and since they are housed in a shell, most have little or no abdominal breathing component. Most pressure changes allowing for lung expansion are accomplished by muscles in the pockets surrounding the fore and hind limbs. Aquatic species respire through their skin and the mucus membranes of the throat and cloaca, while constantly drinking and spitting water (Global World Encyclopedia, 1997).

Most existing species of turtles are amphibious. Both land and aquatic turtles mate in water and lay eggs on land. On average, a female turtle lays 30 eggs at a time, but the sea turtle can lay up to 100-200 eggs. After digging a hole in wet sand and laying eggs, female turtles immediately cover them with soil to protect them. The lifespan of a turtle varies greatly depending on the species of turtle, from dozens of years to over 100 years.

Many symbols based on the biological characteristics of turtles have been incorporated into our lives, depending on social and cultural context. The turtle's fundamental symbol is the cosmic image, with its round back representing the heaven and the square underneath representing the earth floating on the surface of the water. Because the turtle was believed to live for thousands of years, it symbolizes longevity and immortality (Kim, 2005). Cooper also explained that the turtle is a symbol of the ocean or river, the moon, the Mother Earth, the beginning of creation, immortality, fertility, regeneration, and the entire cosmos. It symbolizes 
the universe, with its back as the sky, its bottom shell as the water, and the body in the middle as the earth of the man, or the mediator between heaven and earth (Cooper, 1994).

Because of its cosmic image, people have perceived the turtle as a sacred being with the power of prophecy. In Korea, the turtle has been regarded as an auspicious animal. It foretells the future through its prophetic behavior, bring financial fortune, and deliver the message of gods. It is one of the Ten Symbols of Longevity. In folktales, the turtle is depicted as being wise, given that it has a rich experience in life (Kim, 2010).

The biological characteristics as well as various symbolisms of the turtle have influenced our lives. The most universal symbolism is attributable to its long historical existence, longevity and the image of the cosmos. Such characteristics and images evoke a sense of mystery and awe, which makes us see the turtle as a mystical animal having a full understanding of the cosmic principles.

The turtle not only symbolize divinity, longevity, social status, and authority but also masculine power. It also represents loyalty and dignity as a divine messenger. It is also the god of wisdom with supernatural power. And like Hermes, it is the axis that connects matter and spirit as well as gods and humans. As such, the turtle has a range of symbols according to its characteristics.

Because the turtle can dive deep underwater, it is also associated with death. An endless descent into the deeper realm symbolizes the understanding and redeeming the dark aspects of human nature and overcoming death. It also represents going down to the primal darkness before regeneration and rebirth and experiencing death for the sake of resurrection and ascension (Jung, 1984). In this respect, the turtle's deep dive into the sea symbolizes a journey towards a new life and resurrection after death.

\section{Symbolisms of turtles}

\section{A. Symbolisms Found in Mythologies and Folktales}

Animals in mythologies and folktales representing the human unconscious are 
Journal of Symbols \& Sandplay Therapy, Vol.11 No.1.

symbolically depicted as gods or messenger of gods, or those that repay another's kindness, have profound wisdom, or harm human beings. They sometimes share a common meaning and other times hold a completely different meanings depending on the era and region from which these stories originate (Kim, 2005).

The turtle often plays a very important role in creation mythologies of various ethnic groups. It is often portrayed as a spiritual animal that has learned the cosmic principles. In Korean narratives and fables, the turtle often represents loyalty and wisdom as the messenger of the Dragon King of the sea. It has profound knowledge and wisdom, having accumulated rich experience in life over time. An example narrative is "A Battle of Wits Among the Hare, the Wolf, and the Tortoise" contained in An Outline of Korean Oral Literature (Academy of Korean Studies, 1989).

A hare, a wolf, and a tortoise found a piece of meat while traveling. Because each of them wanted to hog the meat, they made a bet that the one who had gone to the highest point would keep it. The cunning hare looked around, pointed at the highest mountain, and claimed that it had climbed to the peak. The wolf claimed that his back had touched the sky. The tortoise, who was listening quietly, said, "The sky that your back had touched was actually my belly." The turtle won the bet. The hare of the wolf could not admit their defeat and wanted to make another bet. They suggested that the oldest one among them would keep the meet. The hare argued that it has lived for a thousand years. The wolf said he was born when the world was created. Listening to the wolf, the tortoise shed tears and said, "You remind me of my grandson. He died when you were born."

The story shows that even the hare and the wolf, which are often depicted as wily animals, cannot beat the wisdom of the tortoise and end up losing the bet. Another example is the ancient Korean narrative "The Tale of the Turtle and the Rabbit," in which a naïve turtle and a cunning rabbit try to outsmart each other. In this tale, the turtle is depicted as the faithful messenger of the Dragon God of the sea who came to land to carry out the God's will. It is wise but at the same time naïve, and thus ends up being tricked by the rabbit. 


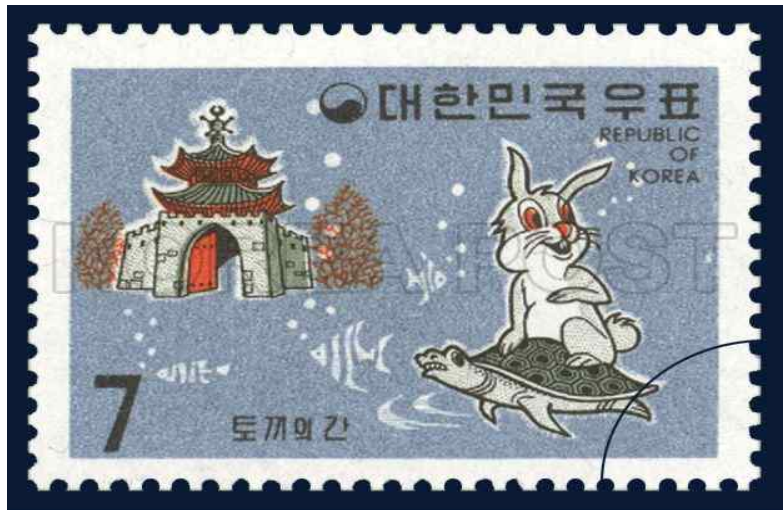

Figure 1. The Turtle and the Rabbit

The tortoise was a fertility symbol in Greek and Roman times and an attribute of Aphrodite/Venus, who was born from the sea, and a label of Hermes/Mercury. In Hinduism, the tortoise as the avatar of Vishnu is the guardian of the world, symbolizing the power of the river and the sea (Cooper, 1978). In "The Tortoise and the Hare," one of Aesop's Fables, the tortoise participated in the race with patience even when knowing that it is slower than the hare. As a result, the tortoise won the race while the arrogant hare took a nap. We can see that turtles in tales and fables usually represent loyalty, wisdom, perseverance and patient and assume the role of a spiritual messenger of gods.

Jung explained that symbols carry universal meanings, and that symbolic expressions are important as they influence every aspect of human thoughts and efforts (Fontana, 1999). Turtles have been expressed as a cosmic symbol related to human life, beyond the symbolisms based on their attributes. In some origin stories, the turtle is said to support the world. Hindus believe that the earth is supported on a world turtle named Akupara (Figure 2 and 3). Akupara is also synonymous with Kurma, the world-turtle which is an avatar of Vishnu, the guardian of life (Figure 4). In Chinese mythology, when one of the four pillars holding up the heavens collapsed from the battle between the god of fire and the god of water, Nuwa, the goddess of creation, salvaged the legs of a turtle to prop up the sky (Figure 5). Ancient Mongolians believed that the mountain located at the center of the world rests upon a turtle. In Japanese mythology, the turtle supports the "Abode of the Taoist Immortals" and the "Cosmic Mountain." In Native American mythology, the turtle is the animal that first created 


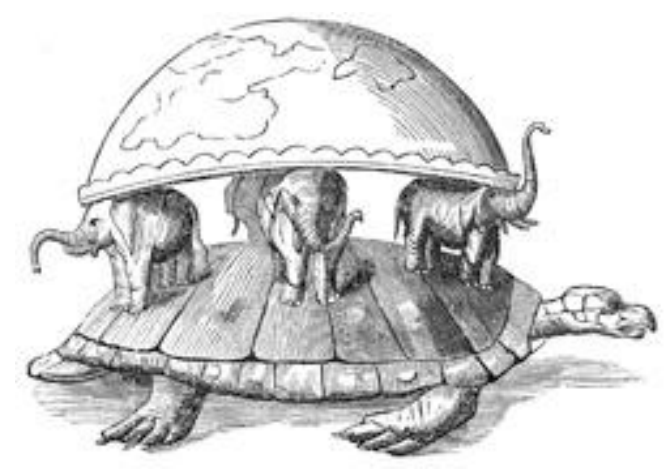

Figure 2. The Hindu Earth.

The "World Turtle" is named Akupara. 1876. Illustrator unknown.

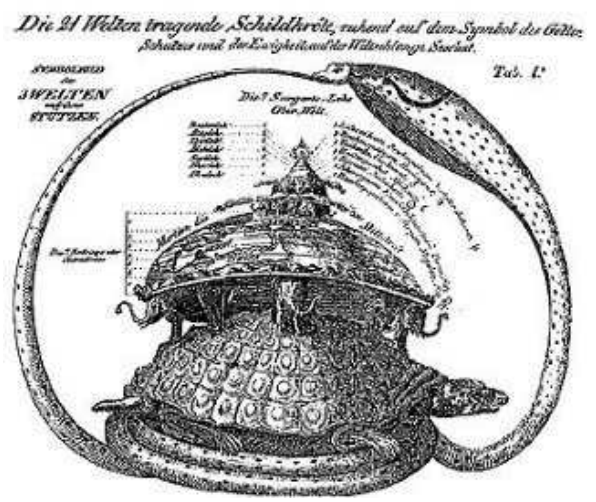

Figure 3. The Hindu Earth

https://m.cafe.daum.net/blackholewhiteh

land by bringing dirt from the bottom of the ocean. The land was so heavy that only the turtle could carry it on its back. As can be seen from the examples mentioned above, turtles are often associated with the origin of various countries and ethnic groups and recognized as a symbol of eternal foundation and the source of all things in the world. This explains why we often see the turtle motif used in architecture and turtle-shaped base for monuments around the world.

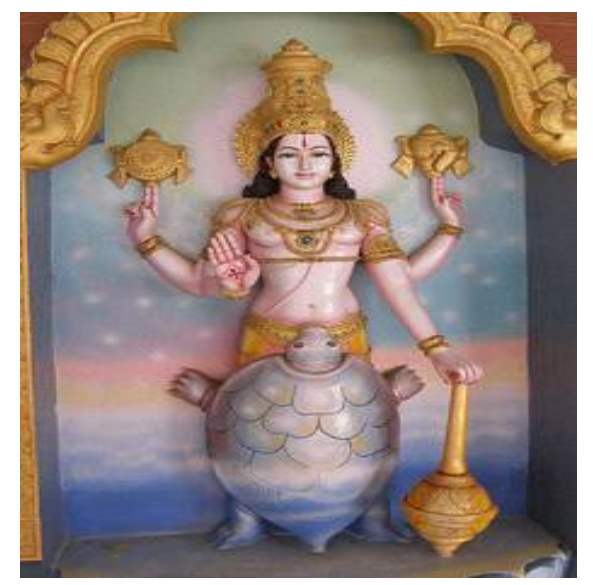

Figure 4. Kurma at Narayana Tirumala. Rajasekhar, 1961.

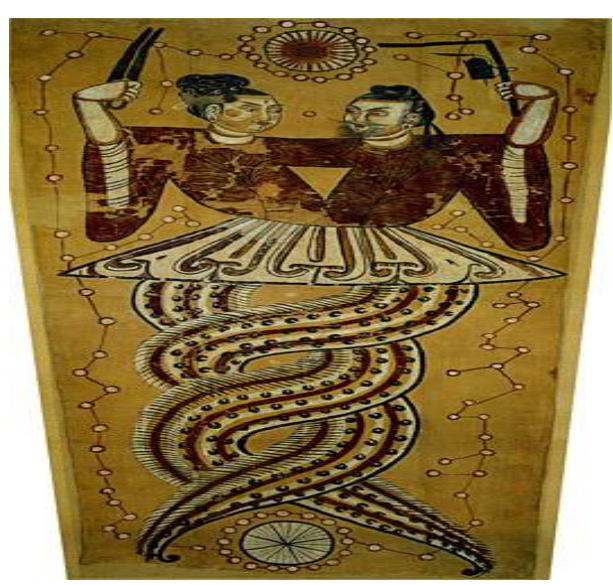

Figure 5. Painting of Fuxi and Nuwa 
People often need a spiritual guide to lead them to a spiritual path. In this respect, the turtle, which enjoy a long life and are amphibious, has long been regarded as a guide for our spiritual life and a mediator that facilitates our spiritual encounter with gods.

\section{B. Symbol of the Animus (Phallus)}

The image of the turtle's head is a symbol of sexuality, as it looks like the male genital. The two also share similarities in terms of their physiology. The belief in the productive power of the male penis led to phallic worship, which later extended to the worshipping of phallic objects (Figure 6 and 7).

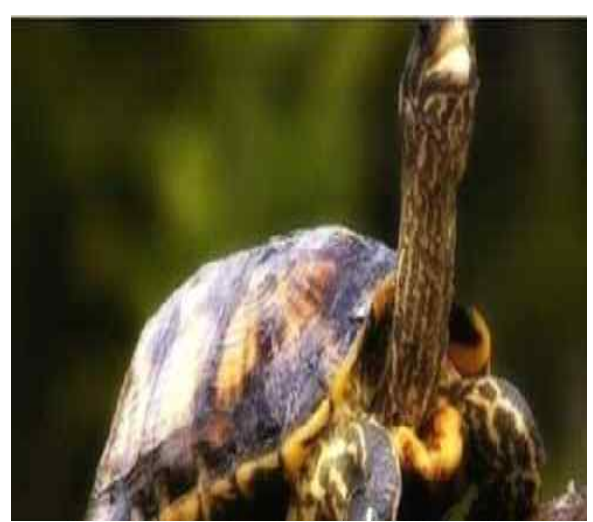

Figure 6. Turtle's head and neck

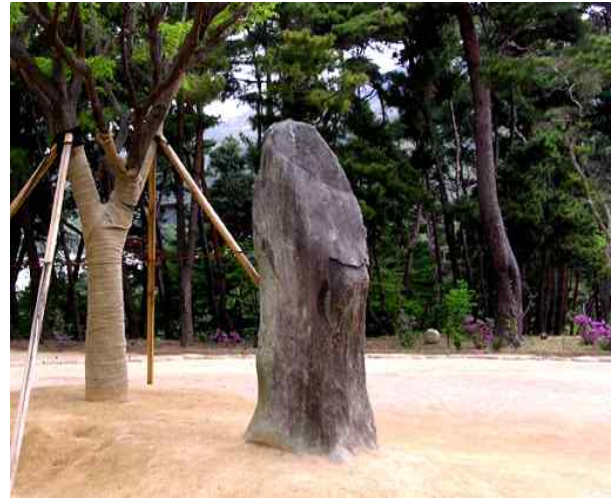

Figure 7. Turtle head totem

As an animal representing vitality and energy, the turtle symbol is an expression of human desire. Therefore, the animus, or the representation of "masculine elements" in women, gave women the assertion of strong energy. If the animus complex becomes too rigid, one's emotional aspects become weak, making it difficult to read the feelings of her own as well as others.

Animus complex can more often be found in women who are successful in life because in a male-centered society, it is easier for women to succeed when they adapt to the culture of men. When a woman enters the world of the masculine without addressing the animus 
Journal of Symbols \& Sandplay Therapy, Vol.11 No.1.

complex, she would accept the negative aspects without criticism and thoughtlessly discard the good aspects. Consequentially, the animus complex becomes negative and distorted. This would enable repressed memories associated with being wounded and betrayed to gain more power, making the woman become even more heartless than the men who remain as negative images in her. As a result, her animus would be wounded even further.

Neumann said that the fruit of individuation for men is knowledge while the fruit of individuation for women is transformation (Jaffe, 1990/2006). Regression of the animus occurs when a woman's consciousness is dominated by the primitive animus in the unconscious, power, and money. But when the animus seeks for spiritual wisdom based on sacrifice and love, it brings creativity to the individual woman and society (Rhi, 2001). By learning how to recognize and accept the animus in their unconscious, women can experience self-integration (Yu, 2016).

For the unconscious to become conscious, one needs to confront the shadows, animus, and anima in the unconscious. The process involves difficulties and pain, as it is the time when we engage in authentic work, experiences struggles, and encounters wounds. And it is at this point in time where we meet the temenos (Friedman et al., 2011). While wounds encountered through authentic work and struggles are very painful, we will obtain authenticity and experience a miracle of transformation within the safe and protective space provided the sacred temenos (Rhi, 2012).

\section{Symbol of Prophetic Being}

From ancient times, turtles have been considered as mystical and sacred creatures that have a prophetic power to predict fortune and misfortune in human life. They were also an object of worship. The turtle shell was used to predict one's fortune. Example includes the practice of burning the turtle shell until it cracked, and then interpret the direction of the crack to predict the future (Figure 8).

Even in Korean history, a statement written on the back of a turtle predicted the fall of ancient kingdom Baekje. According to the chronicles of the three ancient states on the Korean Peninsula, a ghost came inside the palace during the reign of King Uija and shouted 


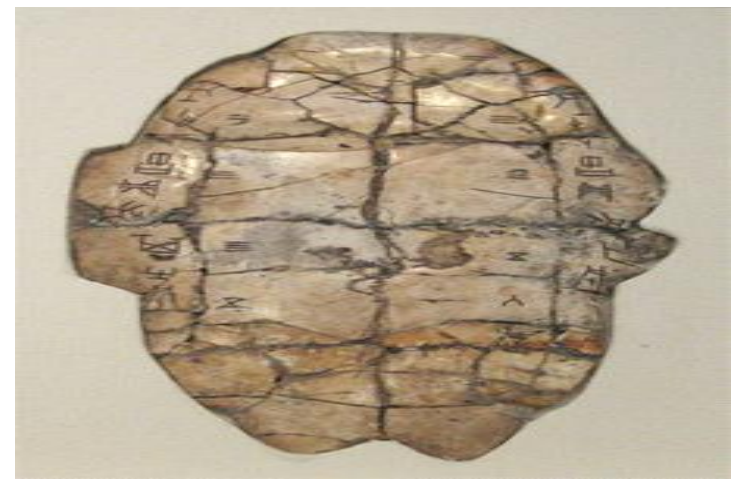

Figure 8. Tortoise plastron

Tortoise plastron with divination inscription from the Shang dynasty, dating to 1,200 BC. Photo by Babel Stone. Wikimedia

"Baekje will fall!" Then it went inside the ground. King Uija found this strange and ordered his subjects to dig the ground. The subjects found a turtle that had "Baekje is like a full moon and Shilla is like a crescent moon." This puzzling code was interpreted to signify Baekje's impending decline and Shilla's rise: "Full moon is full, and full means declining. Crescent moon is empty, and empty eventually gets filled." And it came true when Shilla defeated Baekje. Expecting turtles to play the role of a spiritual guide for human life stems from our spiritual desire for immortality.

\section{Symbol of Chaos and the Union of Opposites}

Chaos symbolizes the call to individuation. In his book The Varieties of Religious Experience, William James explains that many people experience the call to individuation as chaos. He describes Tolstoy's confession of his desire for individuation that consolidated his life with the chaos he experienced within:

I felt that something had broken within me on which my life had always rested, that I had nothing left to hold on to, and that morally my life had stopped. An invincible force impelled me to get rid of my existence, in one way or another. It cannot be said exactly that I wished to kill myself, for the force which drew me away from life was fuller, more powerful, more general than any mere desire. It was a force like my old aspiration to live, only it impelled me in the opposite 
Journal of Symbols \& Sandplay Therapy, Vol.11 No.1.

direction. It was an aspiration of my whole being to get out of life.

Before experiencing chaos, people believe that they know things. They try to be in control of life, without recognizing their shadows that represent our inner desire, which would ultimately result in their experiencing inner chaos. When we do experience inner chaos, we must assume the attitude of trying to find what our inner desires are and what tasks ought to be integrated at that certain point in life. Then, chaos can become an opportunity for individuation.

The rite of passage a shaman must go through have something in common for all race and ethnic groups: The process involves pain, death and rebirth. Taking an active attitude to endure this cruel suffering is acting on god's calling and therefore sacred. To respond to the divine calling, one must endure penance. An aspiring shaman must go through "death." Their limbs are dismembered, and the bones are collected and assembled again (Rhi, 2012).

Mother turtles dig the nest in sand, lay eggs, bury them, and go back to the sea. They head out to the sea, leaving behind the eggs that are as precious as their own lives. In a way, they are leaving their soul in the hands of others. Disappearance of the mother turtle indicates that the eggs are abandoned and exposed to the risk of devastation. But such chaos is a process for new life. Without it, new life cannot be born.

For us human beings, death represents a chaotic state of failure and defeat. Thus no one intentionally chooses death for happiness. But death is actually an essential process for gaining new life and entering the world of resurrection. The pain of death soon leads to the joy of rebirth. Likewise, painful, death-like circumstances in life could be a process of transformation through which we discover a new life and achieve individuation (Edinger, 1985/2014). Corinthians 15: $42-44$ in the New Testament provides a good explanation of this meaning of death:

So will it be with the resurrection of the dead. The body that is sown is perishable, it is raised imperishable; it is sown in dishonor, it is raised in glory; it is sown in weakness, it is raised in power; it is sown a natural body, it is raised a spiritual body.

As both man and god, Jesus Christ contains the opposites and has the transcendent 
function. The image of Christ as a symbol of wholeness would be the symbol of the Self for humans. By sacrificing himself on the cross, Christ provided salvation. The life of Christ represents the transformation process of the Self, which is experienced through the suffering of the individual ego in all human beings (Edinger, 1987).

The path towards the Self through the union of opposites involves the confrontation of numerous conflicts. These conflicts are associated with the desire to integrate opposites in our inner world. we can achieve individuation of self-realization only when accomplishing the process of integration with a mature attitude (Jang, 2010). Growth does not take place if the unconscious is not integrated with the conscious. Our inner conflicts are the voice of the Self, which reminds us not to leave the unconscious as is and instead integrate it with the conscious (Jung, 1985/2004).

Between two opposites, there is a space in which the conscious resides. Psychologically, this means that for us to attain consciousness, we must contain the opposite elements and endure them (Edinger, 1985). We have the tendency to pursue our instinctive drives and to reach a deeper spiritual state, which brings the possibility for both conflict and unity. When these two drives are in a conflict, a symbol for integration appears. When we correctly interpret and act on the symbol, healing through integration occurs and a new self-transformation takes place (Kim, 2013).

Through the turtle symbolism in mythologies, we often see the Self as being represented as a pair of opposites: masculine and feminine, being slow on land and fast in water, etc. The opposites indicate the need for the negative animus to integrate with the personality that it lacks. Although there are "two" that appear contradictory, they are originally one.

Coniunctio oppositorum, or the union of opposites, must ultimately be found within our inner world. In other words, the union between the conscious and the unconscious, man and his anima, and woman and her animus ought to occur within us. In the traditional view on marriage, however, people tried to achieve this union through the literal union between a man and a woman. Within our inner crises-like the experience of inner conflict or agony-or harsh ordeal, there exists the opportunity for transformation: "from tripartite (body, spirit, and soul) 
Journal of Symbols \& Sandplay Therapy, Vol.11 No.1.

to one." In other words, there is the opportunity for the growth of personality integrating all three aspects (Edinger, 1985). The cosmic tree, a symbol for the union of opposites, is a gigantic tree that supports the sky, connects the sky and earth, and also reaches down to the underworld through the roots (Figure 9 and 10).

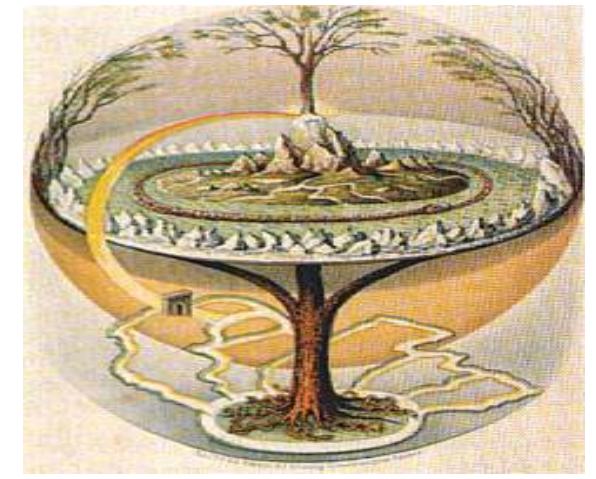

Figure 9. The World Tree. Modern painting of the world tree from an Old Norse mythology.

By Oluf Olufsen Bagge, 1847.

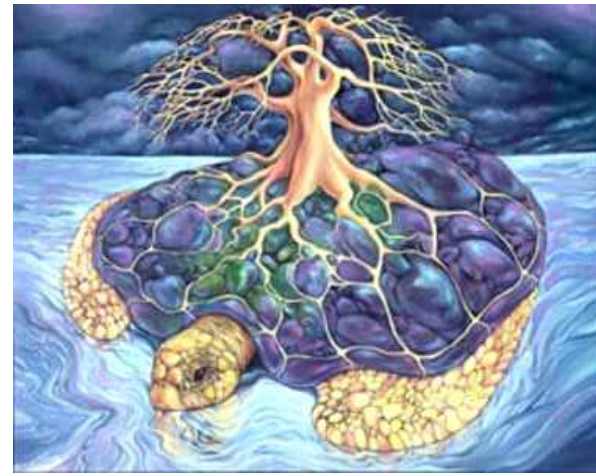

Figure 10. The world tree growing out from the turtle shell, from a Native American mythology.

http://www_crystalinks.com/hopi2.html

\section{E. Entering Individuation through the Turtle Symbolisms}

Individuation is the process by which we become mature as we discover our authentic self. It involves the integration of our innate personality elements, various life experiences, and premature psychic elements into a whole over time. Jung said the process of individualization is a process of self-realization: wholeness centered on spiritual transformation. In other words, our natural drive towards spirituality leads the process of integration within individuation. Despite our utopian expectation to achieve a complete individuation, however, it is impossible to reach a state of perfection (Jang, 2017). This is because human beings and their living environment are imperfect. Therefore, the process of individuation is not about reaching a certain end point at a certain moment. Rather, it is a dynamic process that moves endless towards a certain direction; it is a life-long task. While there is no end, the process allows us to meet our 
authentic Self and enjoy true freedom. We will be able to achieve a more integrated, or unified, personality by gaining a broader view of the world and engaging in dialogue with the deeper layers of the unconscious.

Achieving individuation through the turtle symbolism would indicate the integration of the bright aspects and the dark aspects or despair and happiness, given the turtle's ability to travel on both land and water. It refers to integrating our shadows, the dark elements in our lives that appear as an inner reaction to the every-changing circumstances in life. Shadows are rooted in the unconscious. Through continuous exchange between the conscious and the unconscious, we would be able to recognize shadows as the opposite of the light of the conscious and therefore find our authentic self. The desire of our shadows is the desire of the Self to achieve an integrated self.

Integration of life and death could be reached through the turtle symbolism. The turtle is a symbol of immortality as well as a mysterious mediator who has served both mankind and gods for a long time. Life and death are opposites, and, in some ways, mankind and gods are also opposites. If the opposites are not integrated, individuation cannot be attained. When we integrate life and death, we will recognize death not as something to fear but a natural part of human life, and a stage that must be achieved in the process of individuation. At the core of this process is the relationship between gods and mankind. Men ought not regard gods as a separate being and an object of worship. Instead, through their spiritual aspect, men can become closer to gods as well as become "more close to man." Once the two are integrated, individuation is facilitated. Then gods are no longer the "other" being but a unified being that joins men in every step of the individuation process.

We are born again as a completely different being once we integrate numerous opposite elements-e.g., life and death, gods and mankind, etc.-through the individuation process. This is the experience in which the Self, the center of the psyche, is born anew by coming across the source of our personality. Continuous changes or transformations occur in this process of integration. Jung commented that through individuation, we aspire to become a whole man (homo totus), who is at once the greater and the future of man. He further explained that if we orient the psychic energy, which tilted towards the outer world, towards the inner world, 
Journal of Symbols \& Sandplay Therapy, Vol.11 No.1.

an image that would integrate our lives and guide them to a higher level will appear (Jung, 1985/2004b).

As seen through the turtle symbolism, individuation involves a sense of direction towards being whole. In folktales and narratives, the turtle represents the patience to advance forward to a certain direction without quitting. Likewise, the individuation process requires a clear sense of direction and endless patience, which continues during one's entire lifetime and becomes complete with death. In this process, ceaseless effort to understand our inner world and continued conversation between the conscious and the unconscious are required. If we aim to live life driven by ego and outer achievements, it would not be possible to take care of our inner world. When focusing all our energy on adapting to the circumstances in the outer world, the unconscious would drift apart from the conscious and we would lose our sense of direction. Jung asserted that our psychic energy should not be focused on adaptation to the outer world only. The energy should also be used to focus on our inner world, through which we can recognize the complexes repressed in the personal unconscious and archetypes in the collective unconscious. When we do so, we will be able to attain wholeness and live s life of authenticity. To do so, the ego must first recognize and accept the complexes and the shadows that it had rejected because of their negative qualities. When we go into our inner world and make effort to understand who we are, we will discover our authentic self (Jung, 2003).

According to Jung, the world tree as the axis mudi represents the energy of life, the process of individuation and the Self. Trees have the power to produce, and can represent god's body in its entirety (Rhi, 2003) (Figure 11). The world tree is connected with the idea of the center of the universe, connecting the heaven and earth. It can be seen as a pillar or an axis, through which communication between the heaven and earth becomes possible. The world tree is the central point between time and space, the highest point supported by all creation, the highest point that all creation supports, the axis around which all creation revolve, rules and the essence of all creation (Cooper, 1978/1994) (Figure 12).

Through the process of individuation, or inner integration, in which we meet our authentic self, we become freed from the oppression of the unconscious and experience the joy of living an authentic life as well as self-expansion. Once that occurs, our view of the world 


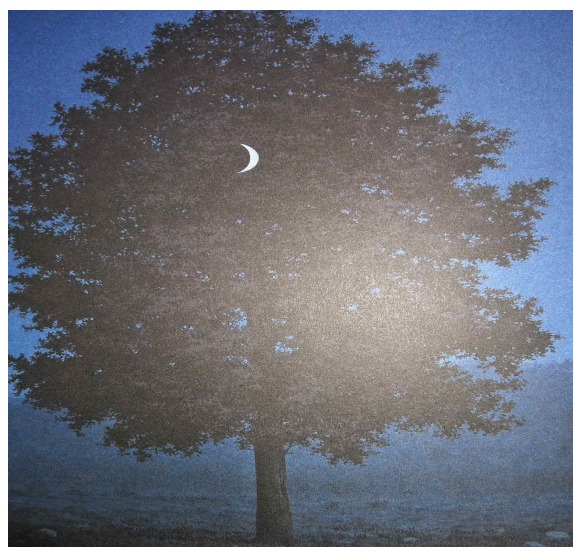

Figure 11. Photograph taken by a camera

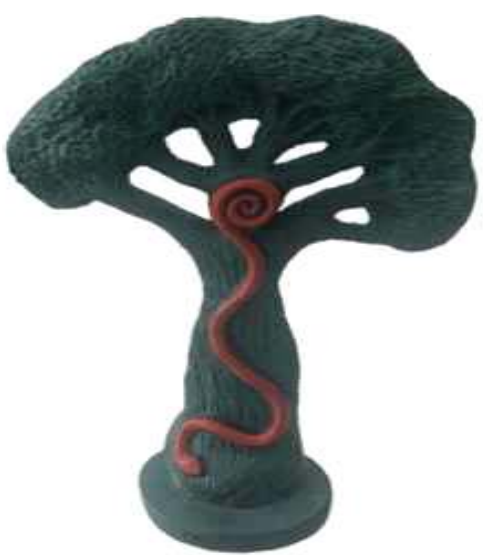

Figure 12. The World Tree

http://www.sandplay.or.kr

would change. People and objects that merely existed as "the other" become integrated into our lives as "the other aspects of myself." This process cannot be accomplished at any one moment. As shown through the turtle symbolism, this is a continuous process experienced at every moment. Once the unconscious is integrated with the conscious, or chaos and darkness with order and light, we would be able to go on a journey of individuation in which we proceed towards a new sense of freedom without remaining complacent.

\section{Symbolisms found in cases of sandplay therapy}

Sandplay therapy involves the use of symbols, which makes it a useful tool to bring our unconscious elements to consciousness and therefore solve problems and achieve self-integration. This part of the paper describes a middle-aged female client who went through process of individuation and self-integration with the help of the turtle symbolism.

The client was a middle-aged woman in her 50 s with two children. She was a professional woman and a practicing Christian. She had passion for life and dreams she aspired to achieve. She had endured challenges and perseverance to achieve her dreams one by one. She had a strong desire to seek for the meaning of her life and true freedom. She also had a 
Journal of Symbols \& Sandplay Therapy, Vol.11 No.1.

strong desire to be recognized by others in terms of her social status and honor. Her husband was self-assertive and authoritative. When unable to suppress his anger, he spoke to his wife in strong language. He regarded his own work as important but not everyone else's. His high-handed, directive behavior initiated conflicts with his sons. The client experienced extreme stress and irritation from the conflict between her husband and children to the point that she even considered a divorce. She complained that taking care of the house and children alone while working was beyond her capacity. The client loved to learn something new, which often resulted in an argument with her husband who believed that she wasn't doing enough to keep the house. The couple also fought often due to differences in their personality, especially as the husband was a perfectionist. The client claimed that her husband did not try to understand her or accept her for who she was.

When experiencing pain and conflict stemming from family-related issues, most middle-aged women face a midlife crisis, feel lost and frustrated as they cannot find meaning in life, and experience confusion and conflict over "who I am." This client had strong desires to achieve her dreams and thus lived her life in a highly dynamic manner, which she identified as her masculine aspect. However, her husband required that she becomes an ideal feminine, domestic wife, and therefore the two frequently engaged in an argument.

In one of her sandpictures, the client placed a cross figure in the left half of the tray (the area of the unconscious) and nothing else. Looking sad, she explained that one cannot meet God without suffering and that the mediator has to always walk on a path of suffering since it has to resolve everything. This comment could be associated with what von Franz said about the process of individuation. Von Franz explained that the individuation process is a conscious dialogue with the Self, and that it begins with the individual feeling pain over his or her wounds. When confronted with the unconscious in the process of individuation to discover the authentic Self, one often experiences a tremendous amount of pain and difficulties (Jung, 2003).

Figure 13-1 is a sandpicture created by the client in her process of individuation to discover the Self. A green turtle appeared in the sandpicture. Green is associated with the meaning of life, love and sacrifice of Jesus Christ, and healing of disease. The client's sandplay 
expressions represent the process of transformation towards a new life, in which she went through struggles involving pain and sacrifice and ultimately found her authentic self within a safe and protected space.

The client's sandplay process dramatically portrayed how she was able to make new transitions (Figure 13-2) by going through suffering and death (Figure 13-1). In this process, the turtle's symbolism as the energy of healing and mediator was shown through the green turtle. This could be seen as the symbol of the Self, as it implies the process of entering a new life. In analytical psychology, the Self is the archetype of wholeness or totality. Kalff (2003) explained that the constellation of the self is the most important moment in the development of personality. A successful manifestation of the Self is a precondition for the development of a healthy ego. As a matter of fact, after the constellation of the Self through

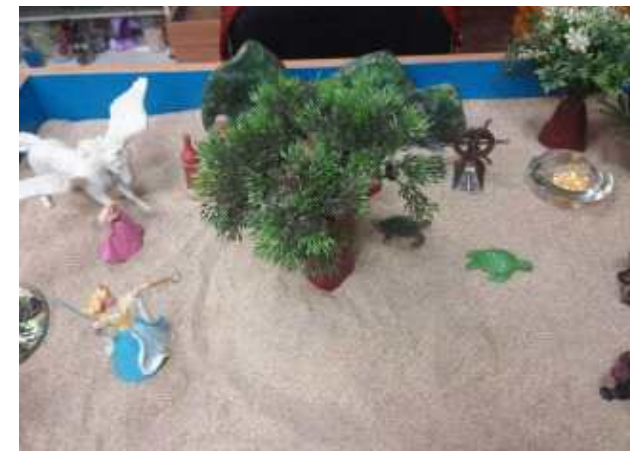

Figure 13-1. Client sandpicture in session 1

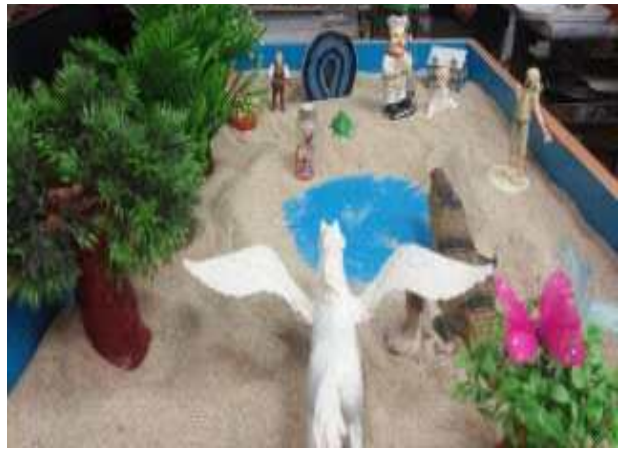

Figure 13-2. Client sandpicture in session 1

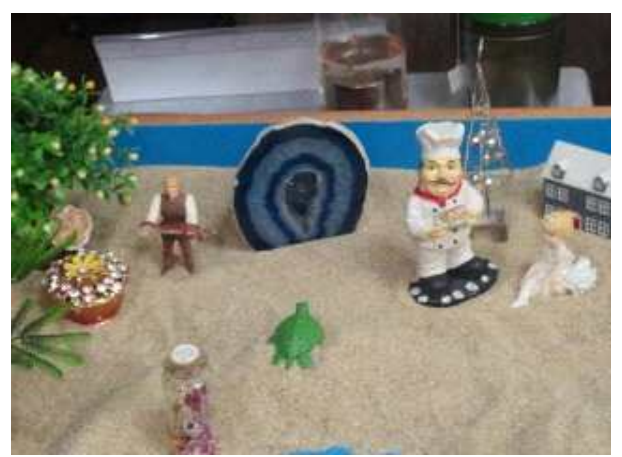

Fig. 13-3. Client sandpicture in session 1 
Journal of Symbols \& Sandplay Therapy, Vol.11 No.1.

the turtle symbol, the client produced a sandpicture in which she heads towards a mandala-like circular gem. While creating this sandpicture, the client talked about following one's dream in association with her desires and passion. The sandpicture and the comment could be an expression of her unconscious desire for the individuation process (Figure 13-3).

The client placed a green turtle at the center of the tray, which looked free and idle. She liked the turtle being there and was surprised to find that it seemed to represent her, although that was not her intention. After the constellation of the Self through the appearance of the turtle, which represents healing energy, the client gained the power to communicate and form a relationship with other people. As in the case of the client, when the Self, which previously remained as an unconscious desire to achieve individuation, becomes integrated with the conscious, it unexpectedly unleashes great energy (Shaia, 2001).

During the initial process of her sandplay therapy, the client experienced the pain of having to confront her unconsciousness. But after integrating her consciousness and unconsciousness and thus discovering the Self, she obtained the energy for healing, achieved ego growth, and experienced increased level of confidence. The constellation of the Self in sandpictures or dreams facilitates the growth and development of the personality and solidifies the growth of the ego.

As suggested by the turtle symbolism in multiple mythologies and folktales, the process of discovering the Self involves great pain and courage. The client, who carried all sorts of burdens with her, represented herself through the turtle, which carries a heavy shell on its back. She also associated the sacrifices she had made in life to the crucifixion of Jesus Christ: One cannot meet the spiritual God above without experiencing the pain of hitting the rock bottom. Her association implies that we must pay a certain price-i.e., suffering, sacrifice and death-to discover our authentic self and gain a new life, which is what individual process and self-integration are all about. The client did not try to avoid the difficult circumstances but instead accepted them as part of her life, thereby finding the opportunity to make progress in her process of individuation and to become spiritually mature to get closer to God. 


\section{Conclusion}

Symbol of the Self represented by the turtle in the client's sandplay process indicated that a new life was beginning. This new life was made possible by discovering and accepting the shadows through the integration of the conscious and the unconscious, which involved both suffering and patience. Jung said the developmental goal of the human psyche is the Self. He emphasized the process of self-realization through which we can become our authentic self. The Self contains the union of the conscious and the unconscious and represents wholeness. To discover the Self, strong courage and patience are required, as illustrated by baby turtles that are born from the egg alone and go out to the sea to face all sorts of dangers and unknowns. Only then will we be able to achieve union between our consciousness and unconsciousness and become closer to being whole.

Symbolisms of the turtle could be found in the client's stories and sandpictures. The turtle allowed her to confront her unconscious and the trauma associated with the memories within. At first, the journey was painful and sad, as it required her to encounter the shadows and negative emotions that she had concealed and discarded. But as the journey gradually progressed, the client began to feel a sense of stability through the symbolism of the turtle, who is able to see and navigate the world of the unknown and ambiguity or the dark unconscious. Her anxiety associated with the fear that other people would find out about her shadows was comforted through the healing energy of the turtle. She also obtained the energy to transform the negative aspects of her shadows so that they could be in the service of her individuation process. In sum, the client felt psychological safety through the spiritual symbolism of the turtle and experienced new healing energy through the green turtle. As a result, the client was able to feel comfortable about confronting her complexes and begin a journey of individuation and self-integration.

Frequent presence of the turtle symbolism implies that there is much to be explored and resolved in relation to the personal and/or the collective unconscious Therefore, it was highly meaningful to take a look at the dream and the sandplay case of this client. In general, dreams produce materials that restore psychological balance in a subtle manner. This was the 
Journal of Symbols \& Sandplay Therapy, Vol.11 No.1.

case for the client, who was able to confront the various energies in her personal unconscious through her dream. She encountered the repressed emotions and experiences associated with the symbols and became aware of her premature attitude of wanting to be successful and become recognized at all times, thereby becoming conscious of her shadows. These shadows then served as useful resources, helping the client to explore deeper layers of the unconscious and to activate various archetypal energies. She experienced the unconscious through the dream in which she descended deep into the ocean while being embraced by the turtle-during which she felt a sense of exhilaration-and received spiritual energy from the turtle symbol present in the sandpicture created right after the dream.

The client's dream heralded the rebirth of the ego, which is necessary for extended consciousness, and also showed that her negative complexes or shadow energies would transform into positive, creative energies. To the client, the turtle was an important symbol that allowed her to confront the shadows of her personal unconscious and become conscious of the energies of the archetypes. She was then able to activate her unconscious with a humble attitude, understand the dynamics of a healthy spiritual psyche, and connected the conscious and the unconscious, which facilitated the creation of a new consciousness for the process of individuation.

In this case study, the turtle is a symbol of life energy as well has healing energy. These energies helped the client accept the anima, which she previously considered as a negative shadow, and experience rebirth through feminine vitality. Images of such process of healing can be found in various religions, folktales and mythologies. For a transformation towards a feminine energy of life to occur, the healing energy of the turtle-a symbol of spiritual messenger, wisdom, divineness, perseverance, and patience-was required. While going through the process of healing in which the anima and the animus were integrated, the client realized that this is what her body and soul had truly wanted.

Symbols serve to convey the energy of life-which consciously or unconsciously supports, guides and synchronizes an individual-to the ego (Edinger, 1972/2016). When we are willing to accept the flow of the symbolic energy, it brings about a change associated with self-realization so that we could attain a new form of positive life. The turtle serves as a spiritual guide for 
continued transformation and rebirth in human life, i.e., the process of individuation towards realizing the authentic Self.

Sandplay therapy makes it possible to see the psychic transformations occurring within clients as it involves reproducing a certain aspect of their inner world. Thus studying the continuity of a sandplay process is highly significant. Kalff (1980) also asserted that the sandplay process is a process of going down into the psyche, the center of the Self. From this point of view, we can see that sandplay is a therapeutic process in which healing occurs through the projection of psychic materials into symbols, which can be the sand, figures, the play itself, or clients' imaginations. For materials to be transformed, it first needs to be "broken," and then a new element must be added or integrated into that "broken" material. Likewise, the existing psychic structure must be "broken" in order for the human ego to obtain new attitudes, experiences, and perspectives (Jang, 2015).

Individuation does not take place without the contrasting relationship of the two genders. Anyone who wishes to reach wholeness must act across the realm of sexual psychology as opposites. Every human being has two sexual aspects, and the one that is dominant over the other determines one's gender. In the process of development, the conscious is differentiated into masculine and feminine, forming the opposites. If the conscious is masculine, then the unconscious is feminine. When the two are not integrated, the unconscious will be seized by the anima in the form of a trapped shadow and therefore remain incapacitated. Union of the anima and the animus is a life-long task that is repeated throughout the entire process of individuation. It is part of self-awareness, union of the opposites that involves the integration of the conscious and the unconscious, and the individuation process to achieve balance and harmony.

\section{References}

Allan, S. (2002). Shape of the turtle: Myth, art and cosmos in early China (Translated by Oh, Manjong). Seoul: Yemonsowon. 
Journal of Symbols \& Sandplay Therapy, Vol.11 No.1.

Bradway, K. (2007). Turtle talk. Journal of Sandplay Therapy, 16(2), 7-11.

Choe, H-W. (2011). A study on human to see through mythology and the nature: focusing on my paintings interpreted as the turtle and stars in the cosmos. A master's thesis in Dondduk Womens University.

Cooper, J. C. (1978). An illustrated encyclopedia of traditional symbol.

Cooper, J. C. (1996). Illustrated encyclopaedia of traditional symbols (Translated by Lee, Yoonki) Seoul: Kacho publisher.

Edinger, E. (1972/2016). Ego and archetype (Translated by Jang, Mikyung). Seoul: Hakjji Publisher.

Edinger, E. (1985). Anatomy of the psyche - Alchemical symbolism in pschotherapy. Open Court Publishing Company. (Trans. into Korea in 2014)

Eliade, M. (1949). Le mythe de i'eternel retour. Paris; Edition Gallimard. (Trans. into Korean in 2003)

Fontana, D. (1999). Secret language of symbols (Translated by Choi, Seung Ja). Seoul: Munhakdongne Publisher.

von Franz, M. L. (1999). The cat: A tale of feminine redemption. Toronto: Inner City Books.

Gillotti, S. (2002). The turtle: Symbol of ancient wisdom and new life. Journal of Sandplay Therapy, 11(1), 51-61.

Jung, C. G. (1984). Menschenbild und Gottesbild. CW4. Princeton: Bollingen/C. G. Jung Institute of Korea. (Trans. into Korea in 2007)

Jung, C. G (1985). Human and Symbol. Seoul: Beomjo Publisher.

Jung, C. G (2001). Grundwerk C. G. Jung: Grundfragen zur Praxis. Seoul: Sol Publisher.

Jung, C. G (2002). Grundwerk C. G. Jung: Traumsymbole des individuationsprozesses (Translated by Jang, Mikyung). Seoul: Sol Publisher.

Jang, D-K. (2010). Mid-life crisis and Jung's theory of individuation process. A master's thesis in Hyup Sung University.

Jang, M-K. (2017). Analytic psychological sandplay therapy. Seoul: Hakjisa.

Kalff, D. M. (2003). Sandplay: A psychotherapeutic approach to the psyche. Temenos Press.

Kim, J-D. (2010). A symbol of our culture the world. Seoul: The Other World. 
Kim, S-M. (2001). Analytical psychology and christianity. Seoul: Hakjisa.

Kim, S-M. (2013). Symbolism of C. G. Jung: The unconscious and religious symbol. Korean Journal of Christian Studies, 85(1), 235-261.

Kim, Y-H. (2005). A study on the symbol of a turtle in the Korean narrative literature. A master's thesis in Graduate School of Korea National University of Education.

Korea Dictionary Research co. (1998). Religious history dictionary. Seoul: Korea Dictionary Research co., ltd.

Rhi, B-Y. (2004). Self and Self realization. Seoul: Hangilsa.

Rhi, B-Y. (2005). Analytical psychology-theory of human mind of C. G. Jung. Seoul: Ilsogak.

Rhi, B-Y. (2011). In-depth analysis of Korean folklore-analytic psychological approach. Seoul: Zipmundang.

Rhi, B-Y. (2012). Shamanism and analytical psychology in Korea. Seoul: Hangil Publisher.

Ryce-Menuhin, J. (1992). Jungian sandplay - The wonderful therapy. London: Routledge.

Shaia, A. (2001). Sandplay's unitive view. Journal of Sandplay Therapy, 102), 89-99.

THE ACADEMY OF KOREAN STUDIES. (1989). A large classification of Korean oral literature. Gyeonggi: THE ACADEMY OF KOREAN STUDIES.

The Grand Encyclopedia of the Korea (1997). Seoul: East-West Culture Publisher.

The Grand Encyclopedia of the World (1970). Seoul: Hagwon Publisher.

Winckel, E. V. (2010). De l'inconscient 'a Dieu: asc 'ese chretienne et psychologie de C.G. Jung (Translated by Kim, Sungmin). Seoul: Korean Psychological Treatment Institute.

Yu, S-Y. (2016). Millstone: The creation of a new coalescence consciousness of opposites. Journal of Symbols and Sandplay Therapy, 7(1), 47-64. 

상징과모래놀이치료, 제 11 권 제 1 호

Journal of Symbols \& Sandplay Therapy

2020, 6, Vol. 11, No. 1, 125-145.

doi https://doi.org/10.12964/jsst.20003

\title{
개성화 입문을 위한 \\ 영적안내자로서의 거북이 양면성이 주는 상징연구
}

A Research on the Turtle's Symbolic Ambivalence and

Its Role as a Spiritual Guide for Individuation Entrance

황 화 란 ${ }^{*}$

Hwang, Hwa Ran

\begin{abstract}
$<$ Abstract $>$
Individuation is a process of human maturity into true self, and a process of self-realization, a holistic process centered on spiritual transformation. Individuation incorporates the unconscious and consciousness existing as an antipole within the mind. We examine this process through the common symbol of the turtle in sandplay therapy. It serves as a mediator between God and Man, thus having an antipole ambivalence of wisdom and chaos. Our case study to examine the role of this symbol was a middle-aged woman. Through turtles appearing in sand therapy of middle-aged woman, we recognized and integrated what is symbolic of human unconsciousness. Sandplay both illuminated and resolved her anger and internal conflict. This fostered the process of individualization and integrated the anima and animus. The results are relevant for understanding the individuation entrance in sandplay therapy. In particular, it aids struggles with self-integration and individuation because of internal conflicts.
\end{abstract}

Keywords : sandplay, symbol, self-integration, individuation, unconscious

* 남서울대학교 아동복지학과 대학원 박사수료 (hhr4908@hanmail.net), 동작아동발달센터 놀이치료사 
Journal of Symbols \& Sandplay Therapy, Vol.11 No.1.

\section{I. 서 론}

인간의 무의식은 상징으로 표현되며, 상징을 통해서 그 자신을 드러낸다. 무의식의 상징 은 감정으로 나타나기도 하는데 현대 사회에서는 불안과 우울로 정신적인 어려움을 겪는 사람들이 많고, 신체적, 정신적으로 피로하고 무력감을 느끼기 쉽다. 그로 인해 현재 자신 의 삶의 의미를 찾지 못해 방황하거나 좌절하며 '나'란 주체성에 대해 고민하고 갈등한다. 또한 현대 사회는 '중년기 위기(midlifecrisis)'현상이 두드러지게 나타나는데, 중년에 들어서서 삶의 무료함과 인생의 허무함으로 고통을 호소하는 사람들을 많이 보게 된다. 그들은 불안 감과 우울증을 호소하고 있으며 변화하는 사회적 배경과 상황들에 제대로 적응하지 못하여 소외감으로 고통 받는다(김성민, 2001).

중년기 위기를 겪는 사람들이 경험하는 삶의 의미에 대한 문제는 자신의 삶의 이야기 중 에서 콤플렉스라고 여겨지는 무의식의 그림자를 발견할 때 비로소 해결될 수 있다. 이것은 융(K. Jung)이 말하는 '자신의 뿌리와 만나는 것'이며, 곧 자신의 삶의 본질적인 부분의 핵 심과 의미 그 자체인 무의식을 통합하는 것이다.

융은 인간의 내면 속에 있는 자기실현을 위한 보편적이고 원초적인 충동을 '개성화 과정' 이라고 설명하였다. 그는 개성화란 인간이 각자 개별적 존재가 되는 것으로 인간이 이 세 상에 태어날 때 가지고 나온 자신의 모든 정신을 남김없이 발휘하고 통합하여 자기(Selbst, Self)의 전체정신을 온전케 하는 것이라고 하였다(이부영, 2002). 이러한 중년여성의 개성화 과정에서 인간은 자기에 대해 더 많은 것을 알게 되기도 하지만 그만큼 갈등과 고통이 수 반되며, 갈등과 고통을 극복하려는 자아의 결단과 용기와 인내심이 필요하게 된다(Winckel, 2010). 인간은 이러한 개성화 과정을 통하여 자신에게 감춰져 있거나 알려지지 않았던 무의 식의 내용들을 의식의 표면으로 떠오르게 한다. 따라서 자신의 무의식 상징의 의미를 올바 르게 파악하고 이해하게 되면 우리의 인식 세계는 더 깊어진다.

융은 의식과 무의식의 통합 과정에서 나타나는 '자기(Self)'의 상징에 대하여, 동물의 상징 형태로 나타날 수 있다고 하였는데, 코끼리, 말, 황소, 곰, 희고 검은 새, 물고기, 뱀, 그리고 거북이의 이미지를 갖는다고 제시하였다(Gillotti, 2002). 이 중 거북이는 한국과 중국에서 용, 봉황, 기린과 더불어 네 마리의 신성한 동물 가운데 하나로 숭배되어 온 동물이며 현재도 존재하는 동물로서 특히 거북이는 둥근 만다라 형태의 단단한 등껍질을 몸에 지니고 다니 며, 수륙양생(水陸兩生)의 특성을 가지고 있어서 육지와 바다를 자유롭게 오가며 속계(俗界) 와 영계(靈界)를 드나드는 신의 사자로 인식되어 온 동물이기도 하다(천진기, 2003).

오랜 세월 사람들의 마음속에서 거북이는 장수, 꿋꿋함(steadfast)과 영리함(knowing), 보호 (protective)와 성장(growing)을 상징한다. 또한 동, 서양의 신화에서 거북이는 장수의 신령한 동물로 그리고 천지의 비밀을 통달한 지혜의 상징이 되며, 바다와 육지 간을 왕래하는 특 
징으로 인해 신의 사자(使者)인 전령으로 인식되어 왔다. Ryce-Menuhin(1992)에 따르면, 거북 이는 딱딱한 등껍질을 지닌 특성으로 인해 모래놀이치료 과정에서 거북이의 등장은 참여자 가 정신적으로 자기 지킴(self-defense)을 잘 한 것을 표현하는 것으로 볼 수 있다고 하였다.

일반적으로 모래놀이치료의 이론적 토대가 되는 분석심리학에서는 인간의 무의식을 탐색 하는 한 과정으로서 꿈 분석을 중시한다. 꿈을 통해서 인간의 무의식의 심오한 상징을 빈 번히 대면하게 되기 때문이다. 특별히, 무의식을 나타내는 꿈이나 모래놀이치료에서 어떤 특정 동물의 등장은 그 동물의 상징에 대해 깊은 관심을 갖을 필요가 있다. 따라서 모래놀 이치료 과정 중 자주 출현하는 거북이 상징은 자기(Self)의 상징으로서, 내면의 통합을 이루 기 위한 의식과 무의식의 상징이 될 수 있고, 나를 찾는 여정의 시작으로서의 개성화 입문 의 과정이 될 수 있다.

본 연구는 한 중년여성 내담자의 모래놀이치료 과정 중 나타난 꿈에 대한 분석이다. 내 담자는 금빛모래에서 거북이 형상이 떠오르며 황금빛 거북이가 모래 속에서 만다라 모양의 등껍질을 드러내며 나타나 그녀를 태워 함께 바다로 떠나는 꿈을 꾸었다. 본 연구를 통해 중년여성인 내담자가 모래놀이치료 과정 중 나타난 거북이의 상징을 통해 '진정한 자기 상 (the true self image)을 만나는 개성화입문 과정이 어떻게 전개되는지 알아보고자 한다.

\section{ㅍ. 거북이의 생물학적 특징}

모든 상징은 사물의 형태나 기능에서 시작되므로, 거북이의 상징을 이해하기 위해서는 먼저 그 생물학적 특징을 살펴보는 것이 필요하다. 동물의 생물학적 특성은 시대, 지역에 관계없이 공통된다. 일반적으로 거북이는 거북목(龜弊目)에 속하는 파충류 중 가장 오랜 세 월 존재해온 동물로서 구조적으로 다른 동물에 비해 기괴한 모습을 하고 있다. 거북의 몸 은 머리·목·몸체·꼬리·사지 등의 부분으로 구성되어 있는데, 몸체는 딱딱한 딱지로 둘 러싸여 있고 배갑(背甲)과 복갑(腹甲)이 결합 상자 모양이고, 놀라거나 휴식할 때는 두경부, 사지, 꼬리 부위를 딱지 안으로 집어넣어 몸을 지킨다(세계대백과사전, 1970).

거북이는 다른 등뼈 동물에 비해 귀갑(龜甲)이라는 뚜렷한 구분이 있는데, 이는 늑골, 등 뼈, 견갑대 등과 같은 골격을 형성하는 부분들의 변형이다. 이 귀갑은 무엇보다 보호를 목 적으로 하며, 다양한 위기적 환경에서 생존을 이어갈 수 있는 이유이기도 하다. 이 무겁고 단단한 껍데기는 거북이만이 지닌 특별한 신체 지지 구조를 가능하게 하고 그에 맞는 근육 체계를 지니게 하여 다른 파충류에 비해 몸속에 많은 양의 물과 음식물 등을 저장할 수 있 게 하였으며, 암컷으로 하여금 많은 양의 알을 낳을 수 있도록 하였다. 이러한 단단한 껍데 기로 인하여 가슴을 움직여 허파에 공기를 들여 마시는 호흡 방법 대신, 내부의 근육과 힘 
Journal of Symbols \& Sandplay Therapy, Vol.11 No.1.

줄을 이용하여 숨을 들이쉬고 토해낸다. 물속에 있을 때는 입으로 물을 마시고 뱉어내면서 인후점막으로 피부호흡을 한다(한국세계대백과사전, 1997).

현존하는 거북이의 대부분은 강, 못 등에 살면서 육지에서도 생활하는 수륙양생(水陸兩 生)의 습성을 갖는다. 거북이는 알을 낳아 번식을 하는데, 육지 또는 물에 사는 종 모두 수 중에서 교미 후 육지에서 알을 낳는다. 보통 한 거북이 배에서 30 개를 낳으며 바다거북이 는 100 200개로 가장 많이 낳고, 거북이 암컷은 구덩이를 파고 알을 낳은 후, 곧바로 훍으 로 덮어 보호한다. 수명은 대체로 수십 년에서 100년 이상 장수하는 것까지 차이가 있다.

이러한 거북이의 생물학적 특성에 기초한 많은 상징들이 사회적, 문화적 배경에 따라 다 양하게 인간 생활 전반에 작용하여 왔다. 신성한 존재로서 여겨지는 거북이의 근원적 상징 은 우주적 심상이다. 이는 생물학적 특징과 관계가 깊은데 둥근 거북의 등은 천공(天空)을 상징하며 밑바닥의 각(殸)은 수상(水上)에 부동하는 대지를 상징하는 것으로 믿어져 왔다. 또한 수천년을 산다고 믿어질 만큼 오래 사는 수명은 장수와 불사를 상징하였다(김영희, 2005년). 이런 의미에서 쿠퍼(Cooper)는 거북이의 상징을 바다나 강, 달, 대지모신(大地母:神), 천지창조의 시작 시간, 불사, 다산, 재생(再生), 전 우주를 상징하며 등딱지는 하늘, 몸은 땅 이나 중간자인 사람, 배의 딱지는 바다라고 하였다(Cooper, 1994).

거북이와 우주의 형태를 동일시한 이러한 우주적 심상은 거북이를 예언적 영험력을 가진 신성한 존재로 인식하게 한다. 거북이는 오랜 옛날부터 우리 민족에게 상서로운 동물로 인 식되었다. 거북이는 예언이나 예조적인 행동으로 미래에 일어날 일을 알려주기도 하고, 재 복을 가져다주는 존재이며, 또한 신의 뜻을 전달해 주는 신의 사자이기도 하다. 특히 거북 이는 장수하는 동물로 알려져 십장생의 하나가 되었으며, 삶의 경험이 풍부하다는 의미에 서 지혜로운 동물로 의인화되기도 한다(김종대, 2010).

이러한 거북이의 생물학적 특징들은 다양한 상징들과 함께 인간 생활 전반에 전해져 왔 다. 거북이의 가장 보편적인 상징적 의미는 거북이의 근원이 오래됨, 장수하는 특성, 거북 이가 지니고 있는 우주적 이미지 등을 통해 나타난다. 이러한 특성과 이미지는 거북이에 대한 신비감과 경외감을 증가시켜 거북을 우주의 원리를 터득한 현묘한 동물로 인식하게 만들었다. 다른 동물과 차별되는 이러한 독특한 형태로 인해 바다와 땅을 오가는 거북이는 하늘과 땅, 신과 인간을 잇는 중재자로 생각되었고, 지식과 예언의 힘을 가진 신령스러운 동물로 여겨졌다.

신적인 의미와 장수와 사회적 지위와 권위의 상징을 나타내는 거북이는 남성적인 힘, 메 신저로서 충성심과 위엄을 나타내는 상징성을 지닌다. 또한 거북이는 지혜의 신으로서 초 자연적인 힘을 가진 신성적인 의미도 내포하며, 헤르메스 같이 신과 인간을 연결해 주는 축으로써 대지와 영, 인간과 신을 이어주는 상징으로 사용되었다. 이렇듯 거북이의 특징에 따라 상징적 의미가 다양하다. 
죽음과 관련해서는 수륙양생하는 거북이가 바다 깊숙이 하강하는 특성이 사용되어진다. 끝없이 깊은 하강은 인간 본성의 어두운 면을 이해하고 그것을 구원하는 것을 상징하며, 죽음을 극복하는 것을 나타낸다. 또한 상징적 측면에서 하강은 재생과 갱생 이전에 태초 의 암흑으로 내려가는 것, 부활하여 승천을 위하여 죽음을 경험하는 것을 나타낸다(Jung, 1984). 이런 측면에서 거북이의 바다 깊은 하강은 죽음을 통과한 후 새로운 생명과 부활 을 향한 여정을 상징한다.

\section{III. 거북이의 상징성}

\section{1. 신화와 민담 우화에 나타난 거북이의 상징성}

인간의 무의식을 상징적으로 표현하고 있는 신화나 민담에서 나타나는 동물의 상징들을 보면, 동물은 그 자체로서의 일차적 의미 이외에 인간이 동물을 어떻게 인식하느냐에 따라 때로는 신 또는 신의 사자(使者)로, 보은의 동물로, 지혜의 주인공으로, 혹은 인간에 해를 끼치는 동물 등 시대와 지역에 따라 공통적인 의미를 띄기도 하고 전혀 다른 의미를 지니 고 있음을 알 수 있다(김영희, 2005).

거북이는 수많은 민족의 창조 신화에서 매우 중요한 역할로 등장한다. 세계의 거북신화 와 전설들을 살펴보면, 거북에 대한 신비감과 경외감을 증가시켜 거북이를 우주의 원리를 터득한 영적인 신령한 동물로 표현하였다. 민담과 우화속에서 등장하는 거북이의 모습은 신(용왕)의 사자(使者)로서의 충성스러움과 지혜로움을 나타내며(김영희, 2005), 오래 사는 동 물인 만큼 인생의 경험이 풍부하다는 점을 보여주는 지식과 지혜의 존재로도 묘사된다. 대 표적인 이야기로 『한국구비문학대계에 수록된』<토끼·늑대·거북이의 지혜 겨루기>를 들 수 있다(한국정신문화연구원, 1989).

토끼 · 늑대·거북이 여행을 가다가 고깃덩어리 하나를 발견했다. 각자가 독차지하 고 싶은 마음에 가장 먼저 높은 곳에 올라가는 자가 먹기로 했다. 꾀 많은 토끼는 주위를 둘러보고 가장 높은 산을 가리키며, 자기가 저 산꼭대기까지 올랐다고 말했 다. 그러자 늑대는 자기 등이 하늘에 닿았다고 했다. 그동안 가만있던 거북이는 늑 대에게, 네 등이 닿은 곳이 바로 내 뱃가죽이라고 말해 내기에서 이겼다. 토끼와 늑 대는 그걸로는 안 된다고 우기면서 다시 내기를 하자며, 나이가 가장 많은 자가 고 기를 차지하자고 했다. 이번에도 토끼는 먼저 자기 나이가 천 살이라고 했고, 늑대 는 이 세상이 생겨날 적에 자기도 태어났다고 말했다. 그 말을 듣고 있던 거북이는 
Journal of Symbols \& Sandplay Therapy, Vol.11 No.1.

눈물을 흘리면서 늑대에게, 너를 보니 손자 생각이 난다고 말했다. 내 손자는 네가 태어날 때 죽었기 때문이라는 것이다.

이 이야기는 꾀 많은 이미지로 표현되는 토끼나 늑대도 거북이와의 내기에서는 항상 지 고 마는, 결국 거북이의 지혜를 따를 수 없다는 것을 말해준다. 또한 우리나라 고대설화인 《귀토지설(敡鬼之說)》에서는 우직한 거북이와 간교한 토끼와의 지혜 겨룸이 나타나는데 거 북이의 충성스러움, 토끼를 꾀는 지혜, 섣불리 토끼를 믿는 순직함, 그리고 용궁과의 관련 성이 나타나며 결국 거북이는 충성스러운 용왕(용궁)의 사자(使者)로 등장하며 신(神)의 뜻을 이행하는 존재로 표현된다(그림 1).

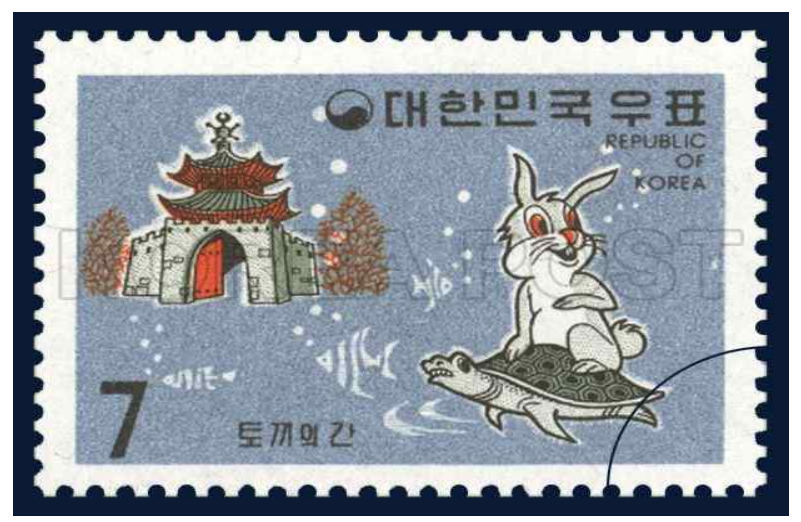

그림 1. 거북이와 토끼

그리스, 로마 신화에서 거북이는 바다의 풍요를 나타내며 바다에서 태어난 아프로디테/ 베누스의 부수물이고 신 헤르메스/메르쿠르스의 표지이다. 또한 세계의 <수호자>로서 비 슈누 신의 화신이며 바다와 강의 힘을 상징한다(Cooper, 1978). 이 외에도 가장 널리 알려져 있는 이솝우화 <거북이와 토끼>에서 거북이는 자신이 느리다는 것을 알면서도 끈기를 가 지고 노력하였고, 결국에는 자신이 빠르다고 자만하여 낮잠을 잔 토끼를 이긴 끈기와 인내 력 있는 존재로 표현되었다. 이처럼 거북과 관련된 민담과 설화에서 나타나는 거북이는 충 성스러움, 지혜, 끈기와 인내를 상징하며 신의 뜻을 전하는 신령한 신의 사자(使者)로 등장 한다.

융은 어떤 상징은 우주적 의미를 지닐 뿐 아니라, 상징적 표현은 인간의 사고와 노력의 모든 측면에 영향을 미치는 중요한 역할을 한다고 하였다(Fontana, 1999). 거북이는 그 자체 의 특성에 기인한 상징성을 넘어서 인간 삶과 연관된 우주적 상징으로 표현되기도 하였다. 거북이와 관련되어 전해 내려오는 이야기 가운데 거북이가 세상을 떠받치고 있다는 내용이 


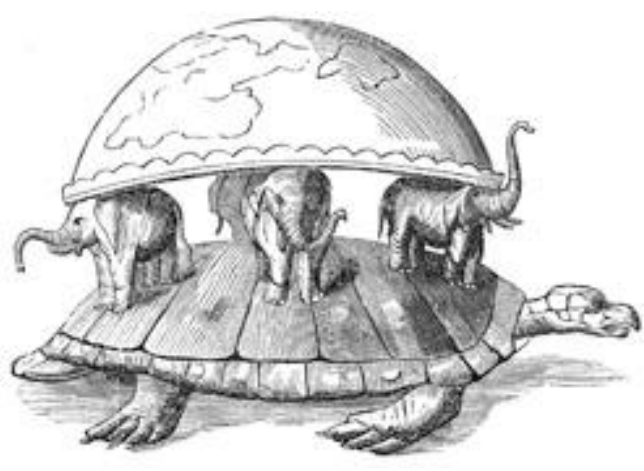

그림 2. 힌두 지구(The Hindu Earth).

"World Turtle "아쿠파라(Akupara)라고 한다. 1876년작. 작자 미상.

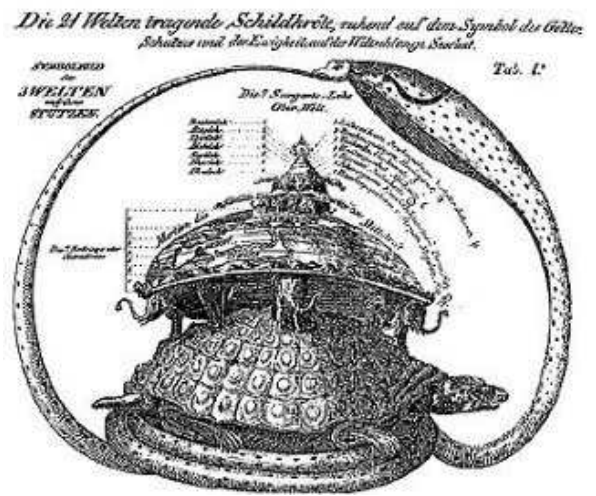

그림 3. 힌두 지구(The Hindu Earth).

https://m.cafe.daum.net/blackholewhitehole/JaCU/ 313?q=D_xowoGfmPRaM0

있다. 힌두교에는 이 세상을 거북이가 떠받치고 있다는 믿음이 있는데(그림 2, 그림 3), 힌 두교 신화에서 생명의 보호자인 비슈누 신의 화신인 쿠르마(Kurma)라는 거북이가 세상을 등으로 떠받치고 있다(그림 4). 중국에서는 물의 신과 불의 신의 싸움으로 인해 세상을 지 탱하는 기둥이 무너지자 창조의 여신 '여왜'가 거북의 네 다리로 기울어지는 세상을 괴었다 는 신화가 있다(그림 5). 몽골에서도 거북이가 세상의 중심에 놓인 산을 떠받치고 있다고 생각했고, 일본 역시 우주 산과 도교의 신선이 사는 곳을 거북이가 받치고 있다고 믿는 이 야기가 있다. 아메리카 원주민들의 신화에서 거북은 바다 밑바닥에서 진휽을 가져다 최초

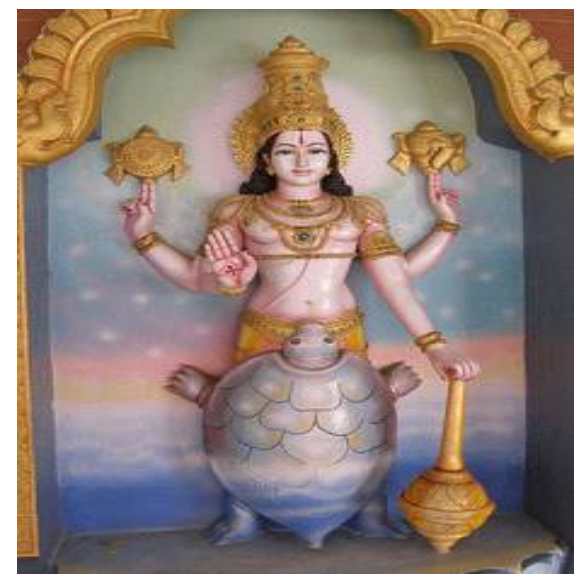

그림 4. 인도의 한 사원(Narayana Tirumala)의 쿠르마. Author /Rajasekhar 1961

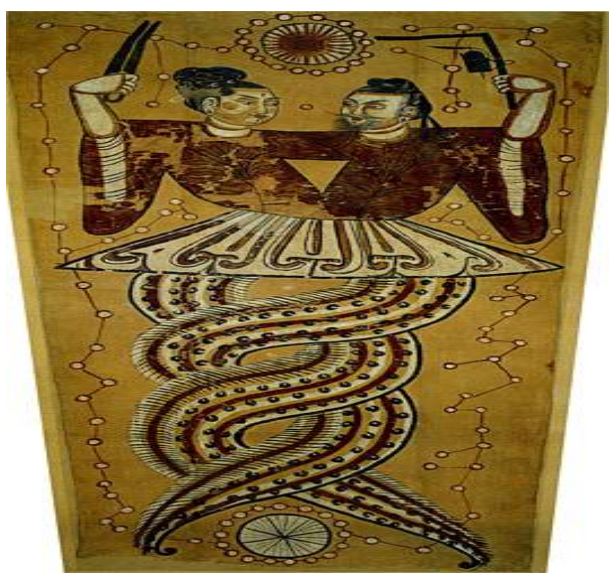

그림 5. "복희씨와 여와" 
Journal of Symbols \& Sandplay Therapy, Vol.11 No.1.

의 땅을 만든 자로 묘사된다. 그렇게 해서 만들어진 땅은 너무 무거워서 오직 거북이만이 등에 짊어지고 실어 나를 수 있었다. 이처럼 거북이는 여러 나라와 민족의 기원과 관련되 고, 세상 만물의 원천이자 영원한 기초의 상징으로 인식되고 있으며 이러한 인식은 세계 여러 나라에서 건축물의 기초로 혹은 비석이나 기념물의 지지대로 거북이의 형상을 만드는 것으로 이어져 내려오고 있다.

신화나 민담에서 거북이가 주는 상징으로 많이 나타나듯이 사람들은 영적존재인 자신을 이끌어 줄 수 있는 영적안내자를 필요로 한다. 그런 측면에서 예로부터 오래 사는 장수의 특징과 수륙양육의 특성을 가지고 있는 거북이는 인간의 영적 삶을 이끌어 주고 신과의 영 적 만남을 위한 중재자로 여겨져 왔다.

\section{2. 아니무스(남근)의 상징으로 거북이}

'성' 상징으로서 거북이의 이미지는 머리이다. 귀두(龜頭)는 형태가 남성의 성기와 흡사하 며, 생리 현상 또한 닮았다. 남성의 성기가 가진 생산력에 대한 믿음은 남근 숭배 신앙을 낳았고, 남성의 성기와 비슷한 사물에 대한 숭배로 확장되었다(그림 6, 그림 7).

이러한 생명력과 힘을 가진 존재로서의 거북이 상징은 사람들이 가지고 있는 어떤 욕망 의 표현이다. 그러기에 여성 속에 '남성적 요소'의 원형으로 존재하는 아니무스는 그 당시 의 여성에게서 강한 에너지의 주장과 확신을 주었다. 아니무스 콤플렉스가 지나치게 경직 되면 감정적 측면이 취약해 상대방은 물론 자신의 감정도 잘 읽지 못한다.

아니무스 콤플렉스는 성공한 여성들에게 더 자주 발견되는데, 남성 중심적 문화에서 여 성이 성공하기 위해서는 아무래도 남자들의 문화에 적응하는 것이 유리하기 때문이다. 여 성 내면에 있는 아니무스 콤플렉스를 잘 해결하지 못하면 남성의 세계에 진입할 때 남성의

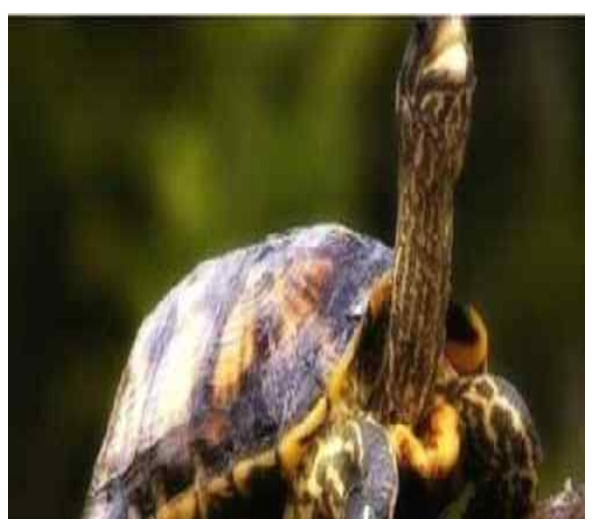

그림 6 . 거북 목 모습

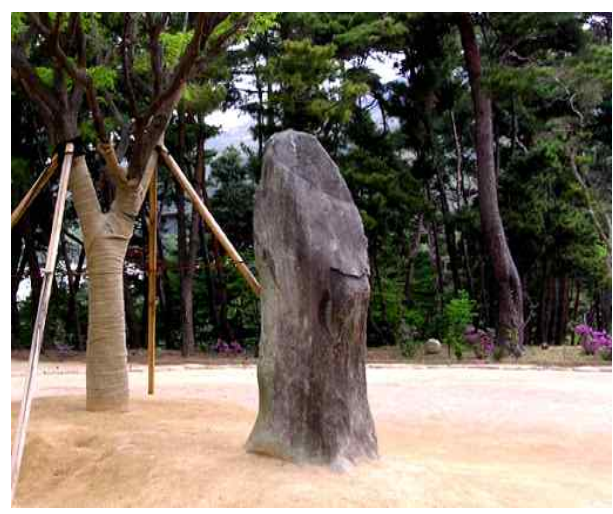

그림 7. 구지가 
나쁜 점은 비판 없이 받아들이고, 좋은 점은 생각 없이 버려서 결국 아니무스 콤플렉스는 부정적이고 왜곡된 형태로 나타난다. 그 결과로 억압받고 상처받고 배신당한 기억이 강하 게 작용하여 자신에게 좋지 않은 이미지로 남아 있는 남성들보다 더 냉혹해지고 그만큼 자 신 속에 있는 아니무스는 상처를 입는다.

Neumann은 남성의 개성화의 열매는 지식이고, 여성의 개성화의 열매는 변화라고 말했다 (Jaffe, 1990/2006). 아니무스의 퇴행은 여성의 의식이 무의식의 원시적 아니무스, 권력과 돈 에 지배될 때 일어난다. 그러나 아니무스가 희생과 사랑을 바탕으로 한 영적인 지혜를 지 향할 때 그것은 창조적 효과를 자기 자신과 사회에 주게 된다(이부영, 2001). 여성은 자신 속에 내재된 무의식의 아니무스를 인지하고 용납하는 방법을 배움으로써 자아의 통합을 경 험할 수 있다(유세연, 2016).

무의식의 의식화 과정을 위해서는 무의식의 그림자, 아니무스, 아니마를 만나게 된다. 이 과정은 힘들고 고통스러움을 경험하게 된다. 진정한 작업과 투쟁을 경험하고 상처로 들어 가게 되는 시점이다. 그래서 이 시점에 테메노스(Temenos)를 만나게 된다(Friedman et., 2011). 진정한 작업과 투쟁을 통한 상처는 매우 고통스럽지만 신성한 테메노스(Temenos)의 안전하 고 보호적인 공간에서 본래의 자기 자신을 찾고 변화의 기적을 만들어 낼 수 있다(이나경, 2016).

\section{3. 예언적 존재의 상징으로서 거북이}

거북이는 예로부터 신성한 존재로 여겨져 인간 삶의 길흥(吉凶), 화복(螎福)을 판단하는 영물(靈物) 또는 신물(神物)로 간주되어 인간의 미래를 알려주는 예언적이며 예지적 동물로 인정받았으며 심지어 신앙의 대상이 되기도 하였다. 그래서 거북이의 등은 앞날의 길흥과 운세를 보는데 사용되기도 하였는데 거북이의 등딱지를 불에 태워 그 갈라지는 모양에 따 라 점을 치는 귀복(龜卜)은 거북이가 미래를 예언한다는 믿음에서 비롯된 것이다(그림 8).

거북이의 예언적 기능을 잘 보여주는 예로써, 백제 의자왕 때 거북이의 등에 기록된 내 용으로 백제의 멸망을 예시한 일이 있다. 삼국사기에 보면, 백제 말 의자왕 때에 대궐 안에 들어온 귀신이 “백제가 망한다"라고 크게 소리치고는 땅속으로 들어갔다. 이상하게 생각한 왕이 그 땅을 파보니 거북이 한 마리가 발견되었는데, 그 등에 '백제는 둥근달과 같고, 신 라는 초승달과 같다라고 씨어 있었다. 이는 '백제는 만월처럼 찼으므로 기울 것이며, 신라 는 초승달 같으므로 장차 흥할 것이다라는 뜻으로, 과연 그 예언대로 백제는 신라에게 멸 망했다. 이처럼 거북이를 통해 인간 삶의 영적안내자 역할을 기대하는 것은 영원불사의 염 원을 가지고 있는 인간의 영적욕구에서 발현된 것이라 할 수 있다. 


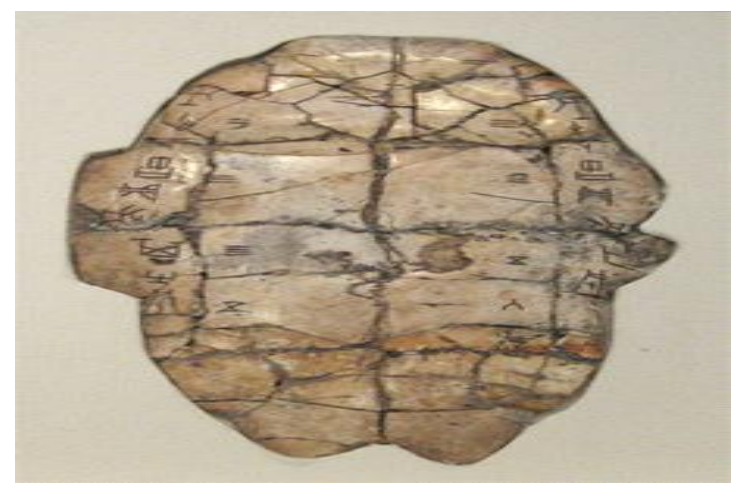

그림 8. 거북 등 딱지

$\mathrm{BC} 1200$ 년경의 은 나라 시대의 거북 갑골. 거북의 배쪽 껍질이며 점치는 문자들이 새겨져 있다. Photo by Babel Stone. wikimedia

\section{4. 혼돈과 대극의 합일을 상징하는 거북이}

혼돈은 개성화로 향한 부르심의 상징이다. 윌리엄 제임스(William James)는 많은 사람들이 개성화의 부르심을 혼돈으로 경험하고 있음을 그의 『종교적 경험의 다양성』이라는 책에서 설명하였다. 그는 자신의 내면에서 경험한 혼돈과 생명을 통합한 개성화의 열망에 대한 톨 스토이의 고백을 다음과 같이 설명하였다.

내가 언제나 의지해왔던 무엇인가가 내 안에서 무너져 내렸고 잡을 아무것도 남아 있지 않았으며, 도덕적으로 내 삶은 중단되었다고 느꼈다. 어떤 대적할 수 없는 힘 이 나로 하여금 이쪽 또는 저쪽으로 나의 존재를 제거토록 하였다. 자살하기를 바 랐는지 정확히 말할 수 없다. 왜냐하면 나를 내 삶에서 몰아낸 그 힘은 원숙하였고 어떤 다른 욕구보다도 강력하였으며 범위가 넓었기 때문이다. 그것은 살고자 하는 나의 옛 열망과 같은 힘이었다. 단지 그 힘은 나를 반대 방향으로 몰고 갔을 뿐이 다. 그것은 삶을 탈출하고자 하는 내적 존재의 열망이었다.

혼돈을 경험하기 전에 사람들은 자신이 제대로 잘 알고 있다고 생각하고 판단하여 욕구 와 열망으로 나타나는 자신의 그림자를 보지 못한 채 삶의 조정하려고 하기 때문에 내적 혼돈을 경험하게 된다. 삶에서 갑자기 내적 혼돈이 다가올 때 자신의 내면에서 열망하는 바가 무엇인지, 자신이 지금 통합해야 할 과제는 무엇인지 깊이 생각하고 찾고자 한다면 혼돈은 개성화를 이루는 기회의 문이 될 수 있다.

샤먼이즘에서의 샤먼의 통과의례 과정에서도 어느 종족을 막론하고 공통적으로 고통과 
죽음과 부활이라는 과정을 거친다. 잔인한 고통을 참는 적극적인 태도를 취하는 것은 신의 소명에 따른 성스러운 고통이다. 정말 소명이라면 고행을 참고 견딘다. 장차 샤먼이 되고자 하는 사람은 '죽음'을 겪어야 한다. 사지가 잘리고 뜯기며 모든 빼가 수집되고 다시 묶인다 (이부영, 2012). 거북이는 바닷가 모래사장에 와서 알을 낳고 모래로 덮고 바다로 사라진다. 자신의 생명과 같은 알을 남겨둔 채 바다로 향한다. 결국 자신의 영혼을 남에게 담보로 하 는 일이다. 또한 엄마 거북이가 사라졌다는 것은 버려진 상태와 황폐화 위험에 노출됨을 의미한다. 하지만 이러한 혼돈은 새로운 생명을 위한 과정이다. 이러한 혼돈의 과정이 없이 는 새로운 생명이 나타날 수가 없다.

죽음은 사람들에게 있어서 실패와 패배의 혼돈상태를 대표한다. 그러기에 누구라도 행복 을 위해 죽음을 의도적으로 선택하지는 않는다. 그러나 죽음은 새로운 생명을 얻고 부활의 세계로 들어가기 위한 필수적인 과정이다. 죽음의 고통은 곧 재탄생의 기쁨으로 이어진다. 삶에서 경험하는 죽음과 같은 고통의 상황들은 결국 자신안에 있는 새로운 생명을 발견하 고 개성화를 이루기 위한 변환과정일 수 있다(Edinger, 1985/2014). 신약성경 고린도전서 15 장 42-44절은 이러한 죽음의 의미를 잘 표현해준다.

썩을 몸은 묻히지만 썩지 않는 몸으로 다시 살아난다. 천한 것으로 묻히지만 영광 스러운 몸으로 다시 살아난다. 약한 것으로 묻히지만 강한 것으로 다시 살아난다. 육체적인 몸으로 묻히지만 영적인 몸으로 다시 살아난다.

인간이면서 신인 그리스도의 대극성과 초월성은 그리스도 상(像)을 하나의 전체성의 상징 으로 볼 때 인간의 자기 상징이다. 그리스도는 숙명적인 십자가 희생으로 구원을 성취하였 다. 이러한 그리스도의 삶은 모든 인간의 개인적 자아(ego)안에서 고통을 통해 겪는 자기 (Self)의 변천과정을 나타낸다.(Edinger, 1987).

대극의 일치를 통해 자기(Self)로 가는 길은 수많은 갈등을 직면하게 된다. 그 갈등은 자 신의 내면세계에서 대극적 요인들을 통합하고자 하는 열망이며 본래적 자기(Self)가 그 통합 과정을 성숙하게 이루어 나갈 때 비로소 개성화 또는 자기실현을 이루게 된다(장동규, 2010). 무의식이 의식에 통합되지 않으면 성장은 일어나지 않는다. 내면의 갈등은 무의식의 존재를 상기함으로써 무의식을 무의식 상태로 내버려 두지 말고 의식과 통합을 이루라는 '자기'의 음성인 것이다(Jung, 1985/2004).

대극인 것들 사이에 의식이 거하는 공간이 존재한다는 것의 심리학적인 의미는 한 개인 이 의식을 획득하려면 대극적인 요소들을 자신 안에 담아서 견뎌내야 한다는 것이다 (Edinger, 1985). 사람에게는 본능적 충동을 추구하려는 성향과 더 깊은 영적 상태에 도달하 려는 성향이 함께 존재하며 충돌과 통합의 여지가 공존한다. 두 가지 충동이 갈등상태에 
Journal of Symbols \& Sandplay Therapy, Vol.11 No.1.

있을 때 통합을 위한 상징이 나타나며 그 상징에 대한 올바른 해석과 행동을 통해 통합에 의한 치유와 새로운 '자기' 변환이 나타난다(김성민, 2013).

신화에 등장하는 거북상징에서도 자기(Self)는 종종 여성성-남성성을 나타내며 육지에선 느리고 바다에선 빠름의 대극적 상징으로 표현된다. 이것은 부정적 아니무스의 결핍된 인 격의 통합이 필요함을 의미하며, 상반되어 보이는 “둘” 일지라도 본래 정신은 하나이다.

'대극의 합일coniunctio oppositorum'은 궁극적으로 자신의 내면에서 찾아야 한다. 개인의 마음속에서 이루어져야 할 합일 즉 의식과 무의식, 남성과 그의 '아니마', 여성적 의식과 ‘아니무스'의 합일을 전통적 결혼관에서는 지나치게 객관적 대상인 이성 간의 결합관계에서 찾으려 했다. 이러한 대극의 합일은 고뇌와 갈등이라는 내면의 위기 같은 혹독한 시련을 통해서 '셋(몸, 혼, 영)에서 하나'가 되는 변환의 기회를 얻게 되며 세 가지가 통합된 인격 으로 성장할 수 있다(Edinger, 1985). 대극의 합일을 상징하는 우주나무는 하늘을 지탱하면서 하늘과 땅을 연결할 뿐만 아니라 뿌리를 통해서 지하세계까지 연결하는 거대한 나무이다 (그림 9, 그림 10).

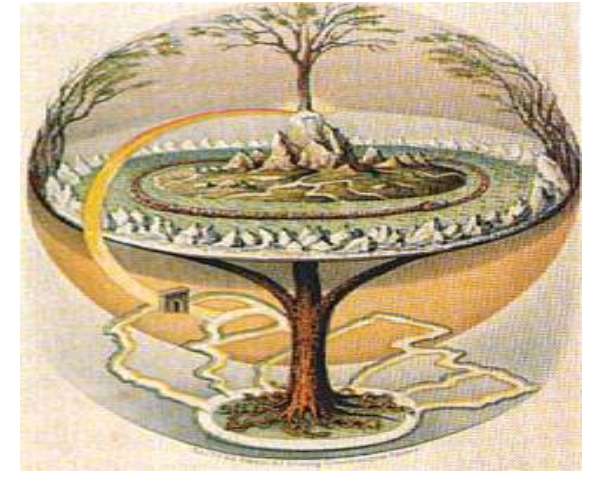

그림 9. 우주나무(World Tree) 북유럽 신화의 우주나무를 현대적인 감각으로 도식화시킨 그림. by Oluf Olufsen Bagge, 1847.

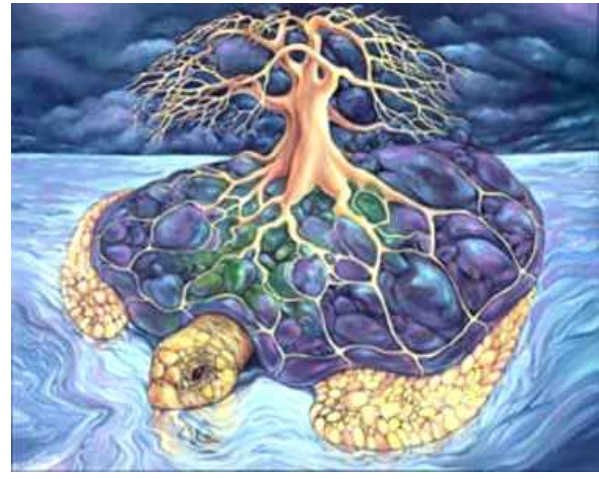

그림 10. 중남미 인디언 문화의 우주나무는 거북 의 등뻐에서 자란다.

http://www_crystalinks.com/hopi2.html

\section{5. 거북이 상징성을 통해 개성화 입문과정}

개성화는 인간이 진정한 자아로 성숙해가는 과정이다. 타고난 성격적 요소들과 다양한 인생 경험, 미성숙한 정신적 요소들이 오랜 세월동안 서로 통합하여 하나의 전체로 완성되 는 과정이 개성화라고 할 수 있다. 융은 이러한 개성화를 영적인 변환을 중심으로 한 전체 성인 자기실현 과정이라고 했다. 즉 인간의 본성 중 신성을 향한 열망이 개성화 통합을 이 
끌고 있다는 것이다. 그러나 완전한 개성화는 유토피아적 기대로 이루고자 하는 개인의 의 도에도 불구하고 그 완전함에 도달하는 것은 불가능하다(장미경, 2017). 왜냐하면 인간의 존 재 자체와 그 살아가는 삶의 환경이 불완전하기 때문이다. 그래서 개성화 과정은 어느 한 순간에 종극적 지점에 도달할 수 있는 것이 아닌 방향성을 가지고 끝없이 움직이는 평생의 숙제이며 이끌어 나가야 하는 활동적 과정이다. 그러므로 진행과정의 끝은 도달할 수 없지 만 인간은 이 과정에서의 노력을 통하여 진정한 '자기'를 만나 더 나은 해방된 자유를 누린 다. 아울러 끊임없이 계속되고 이어지는 개성화 노력을 통해 더 넓은 세계관, 좀 더 깊은 무의식과의 대화를 통해 통합된 인격을 이루어 나간다.

거북이 상징성을 통해 개성화를 이룬다고 할 때, 거북이의 수륙양육 특성에서 나타난 밝 은 면과 어두운 면, 절망과 행복을 통합하는 것을 의미한다. 순간마다 변화하는 삶의 상황 과 그에 대한 내면의 반응으로 나타나는 자신의 어두운 요소인 그림자를 현재 내 삶에서 통합하는 것을 말한다. 그림자는 내면의 무의식에서 발생되므로 의식과 무의식의 끊임없는 교류를 통해 그림자의 어두움과 그늘을 의식의 빛으로 이해하고 용납하면서 진정한 자기를 완성해 나갈 수 있다. 내적 그림자의 욕구는 그 자체로 통합된 나를 이루고자 하는 '자기' 의 욕구이다.

거북이 상징성을 통해 삶과 죽음에 대한 통합을 이루어 나갈 수 있다. 거북이는 불로 불 사적 존재에 대한 상징이며, 신과 인간의 오랜 신비적 중재자 역할에 대한 상징이다. 삶과 죽음은 대극이며 어떤 면에서 볼 때 인간과 신 역시 대극적 관계이다. 이러한 대극적 요소 를 통합하지 못하면 한 인간으로서 개성화를 이룰 수 없다. 따라서 죽음과 삶을 인간 삶의 과정 안에서 통합하여 받아들일 때 비로소 죽음은 인간에게서 두려워하고 멀리 떨어지고 싶은 대상이 아닌 인간 삶의 자연스런 한 요소이며 개성화 과정에서 반드시 이루어야 할 하나의 단계로 인식되어진다. 그 과정의 핵심에 신과 인간의 관계가 존재한다. 신을 단지 인간과 다른 숭배적 존재로서만 여기는 것이 아닌 인간의 신성으로 말미암아 신을 더 닮아 가고, 신 존재로 인해 인간이 더 인간다워지고 개성화를 온전히 이루는데 도움이 될 때 신 과 인간은 통합된다. 그러면 신은 인간에게서 영원한 타자가 아닌 인간의 개성화 모든 단 계에서 인간과 함께 하는 일치된 존재가 된다.

죽음과 삶, 신과 인간과 같은 궁극적으로 수많은 대극적 요소들을 개성화 과정에서 통합 해 나갈 때 인간은 그 전과 전혀 다른 존재로 재탄생한다. 그것은 정신의 진정한 중심인 '자기'가 인격의 근원과 만나 새롭게 탄생하는 경험을 하는 것이며, 이 통합 과정 속에서 지속적인 변화를 나타낸다. 이러한 개성화 과정에 대해 융은 우리가 추구하는 것은 아직 드러나지 않은 보다 큰 미래적 존재인 '온전한 인간 (homo totus)'이라고 했다. 따라서 '외부 로 기울였던 정신적인 에너지를 내면으로 향하게 하여 그곳을 응시하면 거기서 언제나 우 리 삶을 통합시키고, 더 높은 경지로 삶을 이끌어 가는 이미지가 떠오를 것이다라고 하였 
Journal of Symbols \& Sandplay Therapy, Vol.11 No.1.

다(Jung, 1985/2004b).

거북이 상징을 통한 개성화는 끊임없이 완성을 향한 방향성을 의미한다. 거북이에 대한 민담과 설화를 통해 거북이는 느리지만 방향성을 향하여 중도에 포기하지 않고 끝가지 나 아가는 인내를 나타낸다. 개성화 과정 역시 분명한 방향성과 끊임없는 인내력을 지향한다. 이러한 방향성과 인내력은 인간 삶의 전체 과정을 통해 진행되며 죽음과 함께 완성되어진 다. 이 과정에서 필요한 것은 끊임없이 자기 내면을 알아가는 것과 무의식과 의식의 지속 적인 대화가 필요하다. 만일 자아 중심적이고 성취지향적인 삶을 추구하게 되면 인간은 자 신의 내면을 돌보지 않고 당장 눈앞에 펼쳐진 상황의 적응만을 위해 애쓰게 되고 그로 인 해 무의식은 점점 의식에서 멀어지고 개성화 방향성을 잃어버리게 된다. 이에 대해 융은 외면의 적응에만 모든 정신에너지를 쏟는 것이 아니라 내면으로 정신에너지를 돌려 개인적 무의식에 억압하였던 콤플렉스들과 집단적 무의식에 존재하던 원형들을 깨닫게 될 때 전일 성을 이루어 진정한 나로써 삶을 살아갈 수 있다고 하였다. 이를 위해 자아는 먼저 자신의 콤플렉스와 부정적인 특성 때문에 인정하기를 거부하는 그림자를 인정하고 받아들여야 한 다. 또는 인간이 순수하게 내적 세계로 향하고 그 자신을 알려고 노력할 때 진정한 '자기' 가 나타나게 된다고 하였다(Jung, 2003).

융에 의하면 우주축을 상징하는 우주수는 삶의 에너지, 개성화 과정, 자기의 상징이다. 나무는 또한 생산하는 힘을 가지고 있으며, 신의 몸 그 자체이기도 하다(이부영, 2003) 그림 11). 어둠속에서 하나의 밝은 빛을 찾아 가듯이 인간 삶의 자연스러움을 받아들이고 온전한 인간으로 나아가기위해 자기 성찰의 과정으로 나아가는 개성화 과정에서 반드시 이루어야 할 하나의 입문단계로 인식되어진다.

우주수는 세계의 중심개념과 연결되어 있다. 세계의 중심에서 하늘과 땅을 연결시키고 있는 것이 세계수(World Tree)이다. 일종의 기둥, 축이라고 할 수 있는데 이 기둥을 통해 하 늘과 땅의 소통이 가능 해진다. 우주수은 시간과 공간의 중심점, 만물을 떠받치는 최고점, 만물이 떠받치는 최고점, 만물이 그 주위를 회전하는 축, 규범, 모든 존재의 본질이다 (Cooper, 1978/1994) 그림 12).

이렇듯 내면의 통합을 통해 끊임없이 참 '자기'를 만나는 개성화 과정을 통해 무의식의 억압된 삶에서 해방된 진정한 '자기’로 살아가는 기쁨과 자아의 확장이 이루어지면 세계관 이 바뀌고 그로 인해 그동안 타자로 존재한 다른 사람들과 대상들이 '또 하나의 나'로 내 삶 안에서 통합되어진다. 이 과정은 어느 한 순간에 성취되는 것이 아니기에 거북이 상징 이 보여주는 것처럼 끊임없이 그리고 순간마다 경험하는 과정이 되어야 한다. 그럴 때 지 금까지 인간 내면에 존재했던 혼돈과 어두움의 무의식은 밝음과 질서의 의식안에서 통합을 이루게 되어 현재에 안주하지 않고 언제나 새로운 자유를 향해 출발하는 개성화 여행이 될 수 있다. 


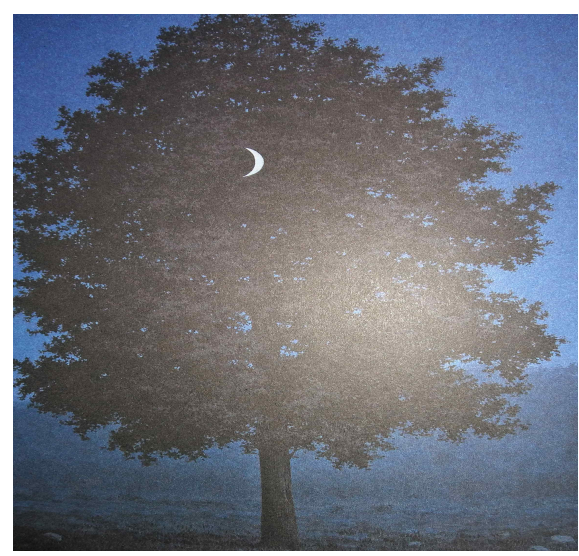

그림 11. 카메라 촬영

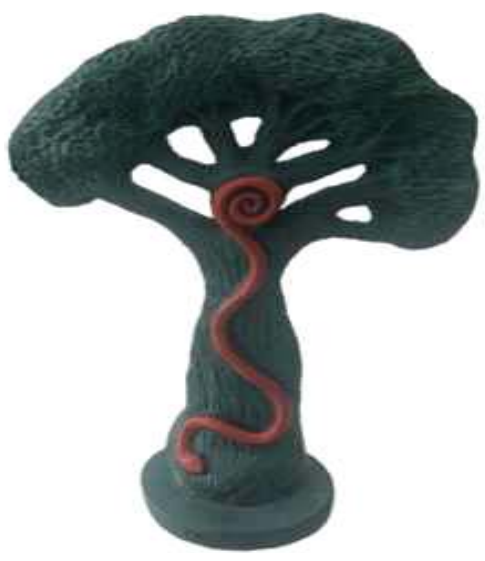

그림 12. 우주수를상징하는 나무 http://www.sandplay.or.kr

\section{IV. 모래놀이치료 사례에서 나타난 거북이의 상징}

모래놀이는 치료과정에서 여러 상징을 사용하기에 개인의 무의식 요소를 의식화하여 문 제해결 및 자기통합을 이루는데 유용하다. 지금부터는 이제까지 거론한 거북이의 상징에 의한 개성화 및 자아통합의 방법을 활용하여 한 중년여성의 개성화 및 자아통합 과정을 다 음과 같이 기술하였다.

나의 내담자는 중년여성으로 50 대이고, 2 명의 자녀를 두고 있으며 전문직 여성으로서 기 독교 신자이다. 그녀는 자신이 성취 하려는 꿈을 갈망하는 열정 있는 여성이며, 자신의 꿈 을 위해서 끝까지 도전하고 인내하고 견디며 지금까지 하나씩 실천하며 살아왔다. 또한 그 녀는 삶의 의미와 진정한 자유를 추구하고 자신의 지위나 명예적인 욕구로서 남에게 인정 받고자 하는 갈망이 강하다. 그녀의 남편은 자기주장이 강하고 권의주의적이며 분노를 참 지 못할 때는 아내에게 거친 표현을 하고 자기 일만 중시하는 성향이다. 그러한 남편의 독 단적 행동과 지시적 성향 때문에 아들과의 갈등관계에 있다. 그녀는 이러한 남편과 자녀들 간의 관계에서 고통과 갈등을 겪으며 스트레스를 심하게 받고 자주 짜증이 나서 이혼까지 생각했다고 말했다. 내담자는 직장생활하면서 혼자 감당하는 생활 경제력과 자녀 양육이 너무나 버겁다고 호소하였다. 또한 내담자는 자신의 꿈과 소망을 찾아 열심히 도전하는 열 정이 있었기에 항상 배우는 것을 좋아하였다. 그러므로 집안일에 충분히 임무를 하지 못한 다고 여기는 남편과 자주 다툼이 있었다. 그녀는 완벽한 스타일을 추구하는 남편과 자주 
Journal of Symbols \& Sandplay Therapy, Vol.11 No.1.

성격차이로 다투었고 남편이 자신을 이해하거나 인정해주지 않음에 대해 많은 불평을 드러 냈다.

위 내담자의 경우처럼 가족이 중요한 문제의 주제로 등장하는 경우 대부분 중년여성은 고통과 갈등으로 인해 중년위기에 겪고 현재 자신의 삶의 의미를 찾지 못해 방황하거나 좌 절하며 '나'란 주체성에 대해 혼란스러움과 갈등을 일으킨다. 내담자의 경우 내면에 자신의 꿈을 위한 소망이 컸기에 매우 활동적으로 자신의 인생을 살려고 하는 성향이 자신이 가지 고 있는 남성성이라고 여겼다. 반면에 남편은 그러한 남성적 성향 및 태도를 보이는 내담 자에 대해 자신이 생각하는 여성성을 지닌 가정적인 아내를 더욱더 요구함으로 둘 사이에 자주 갈등이 생긴다고 내담자는 털어놓았다.

모래놀이 치료과정에서 내담자는 십자가상 소품 하나 만을 좌측(무의식 영역)에 놓고 고 통이 없이는 하나님을 만날 수 없고 중간자는 모든 것을 해결해야 하기 때문에 고난의 길 이라고 설명하며 슬픈 모습을 보였다. 이러한 모습에 대하여 폰 프란츠(von Franz)는 개성화 과정은 내적 중심인 자기(Self)와의 의식적인 대화로서, 개인이 상처를 입고 그것을 고통스러 워하는 데서부터 시작된다고 하였다. 일반적으로 진정한 자기(Self)를 찾아가는 개성화과정에 서 무의식과 대면하게 될 때 개인은 엄청난 고통과 힘겨움을 느끼게 된다(Jung, 2003).

[Fig. 1]의 모래상자는 중년여성이 모래놀이치료를 통하여 자기(Self)를 발견해나가는 개성 화(Individuation) 과정에서 만든 표현이다. 중년여성 내담자 모래놀이치료 그림에 출현한 거 북이는 초록색을 지닌 거북이였는데 여기에 나타난 녹색은 삶의 의미와 그리스도의 사랑과 희생으로 상징되고 질병 치유의 의미가 표현된 것이다. 이러한 내담자의 표현은 마치 진정 한 자기 자신을 발견하기 위해서 고통과 희생이라는 투쟁을 거쳐 결국 안전하고 보호적인 공간에서 본래의 자기 자신을 찾고 새로운 생명을 얻는 재창조의 변환 과정을 나타낸다.

내담자는 모래놀이치료에서 고통과 죽음(Fig. 1)을 거쳐 새로운 전환(Fig. 1-2)이 이루어지 는 모습을 극적으로 보여주었다. 내담자는 그 과정에서 초록색 거북이의 상징을 통하여 치 유의 에너지와 중개자의 역할인 거북이를 상징적으로 표현하였다. 이는 곧 새로운 삶으로 나아가게 하는 입문과정으로 '자기(Self)'의 상징으로 볼 수 있다. Jung의 분석심리학에서 자 기(Self)는 전체성(wholeness or totality)의 원형이다. Kalff(2003)는 자기(Self)의 출현을 인격 발달 에서 가장 중요한 순간이라고 강조한다. 성공적으로 자기를 현현(manifestation)해야만 건강한 자아(ego)의 발달이 이루어질 수 있다는 것이다. 실제로 내담자는 거북이의 상징을 통한 '자 기'(Self)의 출현이 있은 후, 모래상자에서 만다라 모양의 원형 보석 속으로 향하는 모습을 보였다. 이 과정에서 내담자는 자신의 갈망과 열정에 대해 '꿈을 펼쳐라'는 표현을 하였다. 이는 자신의 무의식에서 열망하는 개성화 과정을 표현한 것이다(Fig. 1-3).

내담자는 자유롭게 보이는 모래상자 가운데에 초록 거북이를 안치하고는 좋아 했는데, 


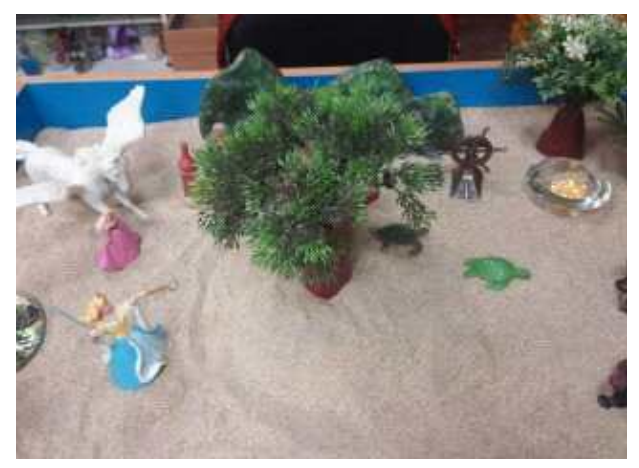

Fig. 1. Client Sandpicture of the $1^{\text {st }}$ session

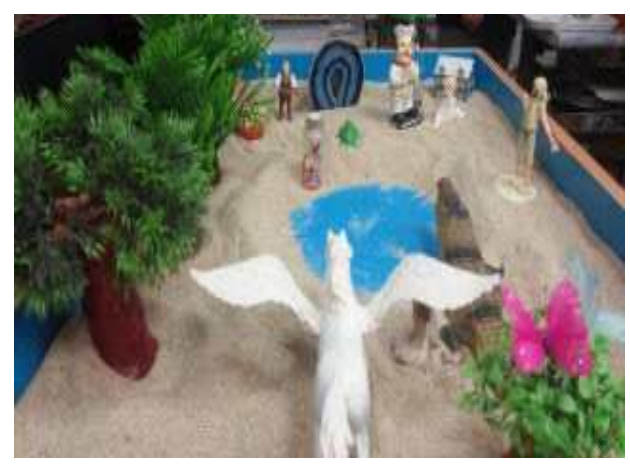

Fig.1-2. Client Sandpicture of the $1^{\text {st }}$ session

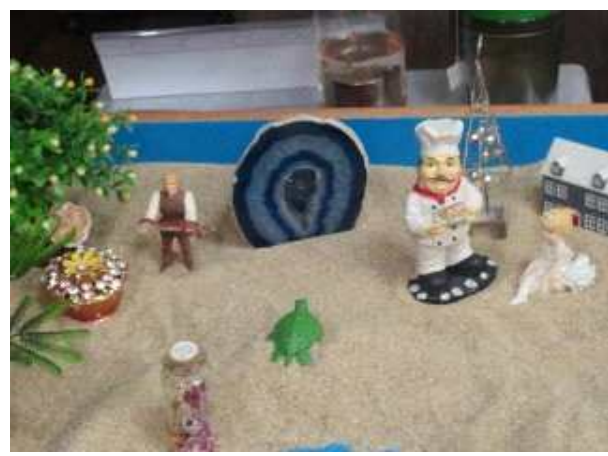

Fig. 1-3. Client Sandpicture of the $1^{\text {st }}$ session

처음엔 자신을 표현하려 했던 것은 아닌데 나중에 보니 자신인 것 같아 놀라워했다. 내담 자는 치유 에너지인 거북이를 상징하는 '자기'(Self)의 출현이 있은 후, 모래상자에서 자신 속에 있는 힘과 기운이 넘쳐서 다른 사람들과 서로 소통하며 관계를 맺는 모습을 나타내었 다. 내담자의 경우처럼 무의식의 열망으로 남아있던 개성화를 이루기 위한 '자기(Self)'가 의 식과 통합을 이룰 때 생각하지 않았던 큰 에너지가 발출된다(Shaia, 2001).

모래놀이치료 과정을 통하여 처음엔 자신의 무의식을 대면하는 고통을 겪던 내담자는 마 침내 무의식과 의식의 합일인 '자기(Self)'에 이르게 되면서 치유의 힘과 에너지가 생기고 성 장한 자아와 자신감이 크게 향상되는 것을 보여주었다. 이같이 모래상자의 표현에서 또는 꿈에 상징(dream symbol)으로 나타나게 되는 '자기(Self)'의 출현은 인격의 발달과 성숙을 가 져오고 개성화를 통한 자아의 성장을 견고히 하게 된다.

많은 신화와 민담에서 거북이 상징에서 볼 수 있듯이, 자기(Self)를 찾아가는 과정은 큰 고통이 따르게 되고 용기 또한 대단히 필요하다. 무거운 등껍질을 지니고 살아가는 거북이 
Journal of Symbols \& Sandplay Therapy, Vol.11 No.1.

처럼 내담자는 자신에 대해 주변의 모든 짐을 지고 가는 거북이에 표현했으며, 자신의 현 재 희생 역시 십자가상 예수를 상기시키고 바닥까지 내려가는 고통이 없이는 위에 있는 영 적인 하나님을 만날 수 없는 것 같다는 표현을 하였다. 이는 마치 진정한 자기 자신을 발 견하기 위해서는 고통과 희생이라는 힘든 대가를 지불해야만 한다는 것을 나타내는 말이 다. 내담자의 이러한 진술은 힘겨운 고통과 갈등, 그리고 죽음을 통해 새로운 생명을 얻게 되고 재창조가 이루어지는 개성화과정과 자아통합을 나타낸다. 내담자는 자신의 현재 힘든 상황을 회피하지 않고 자신의 현재 삶으로 인정하며 그것을 통하여 자신의 개성화 과정을 진행시키고 신과의 접촉을 위한 영적 성숙의 기회로 삼았다.

\section{$\mathrm{V}$. 결 론}

내담자의 모래놀이치료 사례에서 나타나는 거북이의 상징은 자기(Self)의 상징으로서, 삶 의 고통과 인내 속에서 그림자를 발견하고 받아들임으로 의식과 무의식의 통합을 이루며 새로운 생활이 시작되고 있음을 나타낸다. 융(Jung)은 인간 정신의 발전적 목표는 자기(Self) 이며, 진정한 자기 자신이 되는 자기실현의 과정을 중시하였다. 자기는 의식과 무의식의 통 합이고 일치이며, 전체성(wholeness)을 의미한다. 이를 위해서는 마치 알에서 힘겹게 홀로 깨 어 나와 온갖 위험을 무릎 쓰고 새로운 미지의 세계인 바다를 향해 끈기 있게 나아가는 거 북이처럼 힘찬 용기와 인내가 필요하며, 이를 통해 비로소 의식과 무의식의 합일이 가능해 지고 자신의 전체성을 이루어갈 수 있게 된다.

내담자의 이야기 및 모래그림을 통해 상징성을 발견할 수 있었다. 거북이는 내담자로 하 여금 자신의 무의식을 만나게 했고 그 기억 속의 외상(trauma)에 머무르게 했다. 처음에 그 여정은 버려지고 감추고 싶은 그림자를 외면했던 부정적 감정과 만나야 하는 작업이기에 힘들고 고통스러우며 슬픈 감정이 나타났다. 그러다가 점차 이러한 여정이 진행되면서 내 담자는 잘 알지 못하는 세계, 분명하지 못한 세계, 어두운 무의식을 볼 수 있는 역할을 한 거북이 상징성을 통해 점차 안정감을 느끼게 되었다. 그러는 과정에서 내담자는 그동안 다 른 사람에게 자신의 그림자를 들킬까봐 불안해했던 마음을 치유의 거북이를 통해 위로 받 을 수 있었고 그림자의 부정적인 측면을 개성화 과정으로 변환시킬 수 있는 힘을 얻었다. 결국 내담자는 거북이 상징성이 만든 신성함 가운데 심리적 안전감을 느꼈고 초록 거북이 를 통해 전해진 새로운 치유에너지를 경험하였다. 이로 인해 내담자는 자신의 콤플렉스를 편안히 마주할 수 있게 되었고 개성화와 자아통합을 위한 새로운 여정을 시작할 수 있게 되었다.

모래놀이치의 내면세계 탐색을 통한 개성화 과정에서 '거북이' 상징이 자주 등장하는 것 
은 그만큼 개인무의식과 또는 집단무의식의 관계에서 탐색하고 해결해야 하는 내용이 많음 을 의미한다. 따라서 거북이 상징을 통해 내담자들의 꿈과 다양한 모래놀이치료 사례를 통 해 살펴본 것은 더욱 의미 있어 보인다. 일반적으로 꿈은 미묘한 방법으로 마음의 평형성 을 이루는 재료를 산출함으로써 회복시켜 주는데, 내담자 역시 꿈을 통해 개인 무의식의 다양한 에너지와 마주할 수 있었다. 내담자는 상징과 관련된 억압된 정서와 경험을 마주했 고, 어느 곳에든지 성공하고 인정받고자하는 미숙한 태도를 인식함으로써 그림자를 의식화 하기 시작하였다. 그림자의 의식화는 좀 더 깊은 무의식의 탐색을 도왔고 원형의 다양한 에너지를 활성화하도록 돕는 긍정적인 자원이 되었다. 내담자는 거북이 품에 안겨 바다 깊 숙히 하강하는 꿈(하강할 때 환희를 느낌)을 통해 무의식을 경험하였고, 곧이어 창조한 모 래상자의 거북이 상징을 통해서도 영적 에너지를 받았다.

이 꿈은 확장된 의식에 필요한 자아의 재탄생을 알리는 동시에, 내담자의 부정적인 콤플 렉스, 즉 그림자 에너지가 창조적이고 긍정적인 에너지로 변환되고 있음을 보여준다. 내담 자에게 거북이 상징은 개인 무의식의 그림자를 마주하는 것에서 시작하여 원형의 다양한 에너지를 의식화하는 여정을 거쳤고 겸허한 태도로 무의식의 활성화를 통해 건강한 영적정 신의 역동을 이해하고, 나아가 개성화 과정을 위해 의식과 무의식을 연결하여 새로운 의식 창조를 도모하는 중요한 상징임을 나타낸다.

본 연구에서 나타난 거북이 상징은 생명력을 불어넣는 에너지의 상징으로서 내담자는 치 유의 거북이를 이미지화하면서 부정적인 그림자로 여겨졌던 아니마를 받아들이고 여성적 생명력으로 다시 태어났다. 이러한 내담자의 치유의 과정은 치유의 에너지를 담고 있는 상 징성으로 종교적 측면과 민속학적, 신화적 측면으로도 이미지화되어 있었다. 생명의 여성적 에너지로 변화하기 위해서는 수륙양생하는 메신저로서의 거북이와 지혜로움과 영적인 신성 함과 인내와 오래 참음으로 표현되는 거북이 상징의 치유에너지가 필요했다. 내담자는 거 북이를 통해 아니마 아니무스를 통합하는 치유과정을 거치면서 자신의 육체와 영혼(soul)이 이러한 과정을 진정으로 원하는 것임을 깨닫게 되었다.

상징은 의식적 또는 무의식적으로 개인을 지지하고, 안내하며, 동기화하는 삶의 에너지 를 자아(ego)에게 전달하는 역할을 한다(Einder, 1972/2016). 따라서 상징 에너지의 흐름을 기 꺼이 받아들이면 새로운 형태의 긍정적 삶에 이르도록 자기실현의 변화를 가져다준다. 인 간의 삶 속에 변환과 재생으로 끊임없이 재탄생하여 영적 안내의 상징적 의미를 갖는 거 북이는 진정한 자기(Self)를 실현하고자 하는 개성화 과정에 안내자로 메신저 역할을 하는 것이다.

모래놀이치료는 내면의 한 부분을 재현하는 작업을 통해 내담자의 정신적 변화를 알아차 릴 수 있어서 모래상자의 연속성을 연구하는 것은 매우 의미 있는 일이다. Kalff(1980)도 모 래놀이 과정이 자기(Self)의 중심부인 정신 내부로 내려가는 과정임을 주장하며 중요성에 대 
Journal of Symbols \& Sandplay Therapy, Vol.11 No.1.

해 언급하였다. 이런 관점에서 모래놀이치료는 모래, 피겨, 놀이, 상상 등의 상징에 정신내 면을 투사하여 치료하는 심리치료 과정이다. 물질은 변화를 이루기 위해서는 먼저 깨어지 는 단계가 필요하고, 깨어진 물질에 새로운 요소가 추가되거나 혼합되어야 한다. 인간의 자 아 역시 새로운 태도, 새로운 경험, 새로운 조망을 얻기 위해 정신의 기존 구조는 깨어져야 한다(장미경, 2015).

개성화는 성(性)의 대조적인 관련성 없이는 일어나지 않는다. 전체성에 도달하고자 하는 사람은 모두다 대극으로서 성적인 심리의 전체성의 영역을 가로 질러야만 한다. 모든 인간 존재는 두 개의 성을 지니고 있는데, 주로 지배적인 요소가 성을 결정한다. 발달 과정에서 의식은 남성과 여성으로 분화되어 대극으로 이해되어진다. 만약 의식이 남성이라면, 여성은 무의식이다. 이 두 성이 통합되지 않는다면 무의식은 감금상태인 그림자로서의 아니마에 사로잡혀 무력화된 상태로 존재한다. 아니마와 아니무스의 통합은 개성화 과정 동안 계속 해서 반복적으로 돌아오는 평생의 과제로서 자기발견 과정이자 삶 속에서의 의식과 무의식 을 통합하려는 대극의 합일이며 균형과 조화를 이루려는 개성화 과정이다.

\section{참고문헌}

김성민 (2001). 분석심리학과 기독교. 서울: 학지사.

김성민 (2013). C. G. 융의 상징론 - 무의식과 종교상징. 한국기독교신학논총 85(1), 235-261.

김영희 (2005). 한국 서사문학에 나타난 '거북'의 상징적 의미 연구. 한국교원대학교 대학원

석사학위논문.

김종대 (2010). 우리 문화의 상징 세계. 서울: 다른세상.

유세연 (2016). 맷돌: 대극의 합일과 새로운 의식창조의 상징. 상징과 모래놀이치료, 7(1),

47-64.

이나경 (2016). 촛불: 신성한 보호 공간에서의 의식화의 상징. 상징과 모래놀이치료, 7(2), 73-78.

이부영 (2004). 자기와 자기실현. 서울: 한길사.

이부영 (2005). 분석심리학- C. G. Jung의 인간심성론. 서울: 일조각.

이부영 (2011). 한국민담의 심층분석-분석심리학적 접근. 서울: 집문당.

이부영 (2012). 한국의 샤머니즘과 분석심리학. 서울: 한길사.

장동규 (2010). 중년기의 위기와 융의 개성화 과정: 야곱과 모세의 삶을 중심으로. 협성대 석사논문.

장미경 (2017). 분석심리학적 모래놀이치료. 서울: 학지사. 
최혜원 (2011). 신화와 자연을 통해 본 인간 연구: 거북과 우주의 별로 해석된 나의 작품을 중심으로. 동덕여대 대학원 석사학위논문.

한국사전연구사 (1998). 종교학대사전. 서울: 한국사전연구사.

한국정신문화연구원 (1989). 한국구비문학대계. 한국정신문화연구원.

세계대백과사전 (1970). 서울: 학원사 1970.

한국세계대백과사전 (1997). 서울: 동서문화사.

Allan, S/ 오만종 옮김 (2002). 거북의 비밀, 중국인의 우주와 신화. 서울: 예문서원.

Cooper, J. C/ 이윤기 옮김 (1996). 세계문화상징사전. 서울: 까치.

Edinger, E/ 장미경 옮김 (1972/2016). 자아발달과 원형(Ego and archetype). 서울: 학지사.

Fontana, D/ 최승자 옮김 (1999). 상징의 비밀, 서울: 문학동네.

Jung, C. G (1985). 인간과 상징, 서울: 범조사.

Jung, C. G( 2001). 융 기본 저작집. 1권 정신요법의 기본문제. 서울: 솔.

Jung, C. G/ 장미경 옮김 (2002). 융 기본 저작집. 5권 꿈에 나타난 개성화 과정의 상징. 서 울: 솔.

Winckel, E. V/ 김성민 옮김 (2010). 융의 심리학과 기독교 영성. 서울: 한국심리치료연구소.

Bradway, K. (2007). Turtle talk. Journal of Sandplay Therapy, 162), 7-11.

Cooper, J. C. (1978). An illustrated encyclopedia of traditional symbol.

Edinger, E. (1985). Anatomy of the psyche - Alchemical symbolism in psychotherapy. Open Court Publishing

Company. (Trans. into Korea in 2014)

Eliade, M. (1949). Le mythe de i'eternel retour. Paris; Edition Gallimard. (Trans. into Korean in 2003)

Franz von, M. L. (1999). The cat: A tale of feminine redemption. Toronto: Inner City Books.

Gillotti, S. (2002). The turtle: Symbol of ancient wisdom and new life. Journal of Sandplay Therapy, $11(1), 51-61$.

Jung, C. G. (1984). Menschenbild und Gottesbild. CW4. Princeton: Bollingen/C. G. Jung Institute of Korea. (Trans. into Korea in 2007)

Kalff, D. M. (2003). Sandplay: A psychotherapeutic approach to the psyche. Temenos Press.

Ryce-Menuhin, J. (1992). Jungian Sandplay-The wonderful therapy. London: Routledge.

Shaia, A. (2001). Sandplay's unitive view. Journal of Sandplay Therapy, 10(2), 89-99.

투고일 : 2020. 03. 30

게재확정일 : 2020. 05. 08 